\title{
Evolution of the aerosol, cloud and boundary-layer dynamic and thermodynamic characteristics during the 2 nd Lagrangian experiment of ACE-2
}

\begin{abstract}
By SIMON R. OSBORNE ${ }^{1 *}$, DOUGLAS W. JOHNSON ${ }^{1}$, ROBERT WOOD ${ }^{1}$, BRIAN J. BANDY ${ }^{2}$, MEINRAT O. ANDREAE ${ }^{3}$, COLIN D. O'DOWD ${ }^{4}$, PAUL GLANTZ ${ }^{5}$, KEVIN J. NOONE ${ }^{5}$, CHRISTOPH GERBIG ${ }^{6}$, JOCHEN RUDOLPH $^{7}$, TIMOTHY S. BATES $^{8}$ and PATRICIA QUINN ${ }^{8}$, ${ }^{1}$ Meteorological Research Flight, Farnborough, UK; ${ }^{2}$ School of Environmental Sciences, University of East Anglia, Norwich, UK; ${ }^{3}$ Biogeochemistry Department, Max Planck Institute for Chemistry, Mainz, Germany; ${ }^{4}$ Centre for Marine and Atmospheric Sciences, University of Sunderland, Sunderland, UK; ${ }^{5}$ Department of Meteorology, Stockholm University, Stockholm, Sweden; ${ }^{6}$ Department of Earth and Planetary Sciences, Harvard University, USA; ${ }^{7}$ Centre for Atmospheric Chemistry, York University, Toronto, Canada; ${ }^{8}$ NOAA/PMEL, Seattle, USA
\end{abstract}

(Manuscript received 15 February 1999; in final form 9 September 1999)

\begin{abstract}
We present observations from the 2nd Aerosol Characterisation Experiment where over a 29-h period between 16-18 July 1997 a tagged column of air was followed by a fully instrumented aircraft. The Lagrangian framework this offered made it possible to measure the evolution of the aerosol size distribution, the cloud structure and microphysics, and the dynamic and thermodynamic structure of the marine boundary layer within a polluted airmass advecting off northwest Europe over the sub-tropical North Atlantic Ocean. The salient observations are presented and analysed. Processes responsible for the evolution are suggested, but quantification of their respective rates must be taken up by future modelling studies. Stratocumulus capped the boundary layer throughout the period that produced negligible washout of aerosol. This implies that the conversion of a continental to a maritime airmass within the cloud-capped sub-tropical marine boundary layer is not controlled by the drizzle process but by entrainment from the free troposphere. We find evidence of processing of aerosol particles by stratocumulus cloud, in particular by aqueous-phase reactions. The processing of the aerosol, realised by modification of the aerosol size distribution in the particle diameter range $0.1-0.5 \mu \mathrm{m}$, was complicated by rapid changes in boundary layer height and structure, and also by entrainment of both polluted and relatively clean aerosol from the free troposphere. The cloud microphysics was affected by these changes in the boundary layer aerosol through changes in the cloud condensation nuclei activation spectra. The cloud microphysics was also strongly affected by changes in the dynamics of the boundary layer which included variations (e.g., diurnal) in cloud thickness and an increase in vertical wind speed. Thermodynamic changes within the boundary layer included decoupling due to an increasing sea-surface temperature and a change in the subsidence rate in the free troposphere superimposed on diurnal decoupling. Hypotheses have been devised so that future modellers can focus their efforts to either validate or invalidate potentially important processes.
\end{abstract}

* Corresponding author address: Dr Simon R. Osborne, Meteorological Research Flight, Y46 Building, DERA Farnborough, Hampshire, GU14 OLX, UK.

e-mail: sosborne@meto.gov.uk

Tellus 52B (2000), 2 


\section{Introduction}

Aerosols are poorly represented in atmospheric global circulation models (AGCMs) because of a lack of well-conducted field experiments, wellformulated process models, and subsequent development of parametrisations based on empirical data. These AGCMs determine the radiative impact of aerosols on the global climate. Aerosol forcing of climate can be divided into two broad forms - a direct forcing whereby the aerosol particles interact directly within solar and terrestrial radiation fields, and an indirect forcing whereby the aerosol particles modify a radiatively active atmospheric constituent such as clouds and trace gases. The indirect effect of aerosols will hereafter refer to the modification of low-level warm clouds, in particular stratocumulus due to its large global coverage and high albedo relative to the underlying (mostly oceanic) surface.

The first indirect effect of aerosols is described by the Twomey (1977) effect: increased levels of pollution contain increased loadings of cloud condensation nuclei $(\mathrm{CCN})$ which increase the cloud droplet concentration and, for a fixed liquid water content $\left(q_{\mathrm{L}}\right)$, decrease the mean size of the droplets thus increasing the optical depth $(\tau)$ and hence cloud albedo. The second indirect effect of aerosols relates to changes in drizzle production, i.e., increases in $\mathrm{CCN}$ concentrations produce more cloud droplets having a higher colloidal stability, reduced coalescence rates and hence increased conservation of cloud liquid water. This process potentially affects cloud lifetime and fractional cover (Albrecht, 1989). Globally, the indirect effects have not been quantified with confidence but both potentially produce comparable negative forcings, possibly providing a total forcing in the region of -1.6 to $-3.2 \mathrm{~W} \mathrm{~m}^{-2}$ (Rotstayn, 1999). The total forcing due to all greenhouse gases has been much more confidently placed at +2.5 $\mathrm{W} \mathrm{m}{ }^{-2}$ (IPCC, 1995).

Low-level clouds are known to modify the size and chemistry-resolved spectrum of aerosol particles by physical and chemical processes (Hoppel et al., 1986). Possible physical processes include cloud droplet coalescence and scavenging of interstitial particles by the cloud droplets. Chemical processes include the production of sulphate and nitrate (Clegg and Toumi, 1997) by the oxidation of dissolved $\mathrm{SO}_{2}$ and $\mathrm{NO}_{\mathrm{x}}$ trace gases (Jenkin et al., 1996). Feingold et al. (1996) indicated through modelling studies that aqueous-phase reactions can dominate aerosol processing for low liquid water contents, but coalescence can be as effective for high $q_{\mathrm{L}}\left(>0.5 \mathrm{~g} \mathrm{~kg}^{-1}\right)$ where the droplet spectrum is broad.

Previous observations (Hoppel et al., 1994) and modelling studies (Kerminen and Wexler, 1995) have shown that the aerosol size distribution is split (by the so-called Hoppel dip) into a cloud residual mode (containing the $\mathrm{CCN}$ at sizes generally $>0.1 \mu \mathrm{m}$ ) and a cloud interstitial mode which contains particles too small (generally $<0.1 \mu \mathrm{m}$ ) to act as CCN within stratocumulus. Such cloud processing can potentially affect the radiative (Yuen et al., 1994) and cloud-forming (Bower and Choularton, 1993) properties of those aerosol particles.

Interaction of aerosol and cloud within the marine boundary layer (MBL) with aerosol from the lower free troposphere (FT) by way of entrainment of FT air into the MBL has also received attention in the recent literature (Raes, 1995). Observations during the first Aerosol Characterisation Experiment (ACE-1) within the clean MBL over the oceanic region to the south of Tasmania show that entrainment of secondary particles formed in the FT into the MBL is a process that is an integral part of the aerosol-cloud cycle in that region of the world (Clarke et al., 1998). Van Dingenen et al. (1999) showed through modelling studies that entrainment of aerosol (of relatively low particle concentrations) from the FT into MBL is the single most important process controlling the relationship between total sulphate mass and the number of $\mathrm{CCN}$ within a continental airmass advecting over the ocean. Therefore entrainment could be an important influence on the radiative properties of a cloud layer.

The only way of measuring the evolution of an airmass is in a Lagrangian framework, where substantive changes are measured following the motion. During the second Aerosol Characterisation Experiment (ACE-2) in the sub-tropics of the North Atlantic this was carried out in the field using an aircraft by tagging an air parcel with smart balloons and a tracer gas. The aircraft then followed the air parcel for as long as was practicable. (See Johnson et al. (2000a) for an overview of the Lagrangian experiments.) The present paper compliments the two other Lagrangian focus 
papers, Johnson et al. (2000b) and Wood et al. (2000).

The Lagrangian discussed here that took place between 16-18 July 1997, together with other cloudy experiments conducted throughout ACE-2 (Brenguier et al., 2000), attempts to increase our knowledge of the interaction of aerosol particles and warm MBL clouds, particularly within continental airmasses. The salient observations are presented and analysed. While processes responsible for the evolution are suggested, the rates of these must be quantified by future modelling studies. This will contribute eventually to the overall aim of ACE-2 which is to assess the aerosol radiative forcing over the North Atlantic region.

\section{Aircraft measurements}

The analysis in this paper was carried out primarily through the use of aircraft data gathered by the Meteorological Research Flight C-130 aircraft. The primary instruments used in this paper are: Particle Measuring System's (PMS) passive cavity aerosol spectrometer probe (PCASP-100X) measuring aerosol particles over the diameter range $0.1-3.0 \mu \mathrm{m}$ (i.e., essentially the accumulation mode); PMS forward scattering spectrometer probe (FSSP-100) measuring cloud droplets (and coarse mode aerosol particles) between 2 and $47 \mu \mathrm{m}$; PMS 2D cloud probe (2D-C) measuring cloud droplets in the range 25 to $800 \mu \mathrm{m}$; TSI condensation nuclei $(\mathrm{CN})$ counter 3025 counting all particles down to a nominal $3 \mathrm{~nm}$; and a $\mathrm{CCN}$ spectrometer which uses a thermal gradient chamber device (Saxena and Kassner, 1970).

All the other instrumentation and techniques that have been used in this paper are described in Johnson et al. (2000a). For fuller descriptions of turbulence measurements see Rogers et al. (1995) and for further details of the cloud physics suite of instruments see Brown (1993). The techniques used for aerosol sampling and chemical analysis are described in Andreae et al. (1988).

Three back-to-back flights (A558, A559 and A560) that constituted the second Lagrangian were carried out from the base in Tenerife. The start and end times of aircraft operations within the tagged air parcel for each flight and the position of the balloons at these times are summarised in Table 1. The flights took place at night-
Table 1. Flight details for Lagrangian 2 that was carried out between 16-18 July 1997

\begin{tabular}{ccccc}
\hline $\begin{array}{c}\text { Flight } \\
\text { no. }\end{array}$ & $\begin{array}{c}\text { Start time } \\
{[\text { UTC }]}\end{array}$ & $\begin{array}{c}\text { End time } \\
{[\text { UTC }]}\end{array}$ & $\begin{array}{c}\text { Start pos. } \\
{\left[{ }^{\circ} \mathrm{N} ;{ }^{\circ} \mathrm{W}\right]}\end{array}$ & $\begin{array}{c}\text { End pos. } \\
{\left[{ }^{\circ} \mathrm{N} ;{ }^{\circ} \mathrm{W}\right]}\end{array}$ \\
\hline A558 & 0000 & 0400 & $40.1 ; 11.1$ & $39.2 ; 11.6$ \\
A559 & 1100 & 1630 & $36.8 ; 12.8$ & $36.2 ; 13.5$ \\
A560 & 2300 & 0500 & $33.7 ; 14.3$ & $32.6 ; 14.5$ \\
\hline
\end{tabular}

The start and end times refer to the start and end of the C-130 observations in the tagged column of air for each flight. The start and end positions give the approximate positions of the centre of the box (i.e., the approximate balloon position) that correspond roughly with the times.

time, day-time and night-time respectively, such that visual observation of the cloud structure could only be made during A559. Two smart balloons (Johnson and Businger, 2000) were released from the ACE-2 ship RV Vodyanitskiy at 2200 and 2300 UTC (at position approximately $39.7^{\circ} \mathrm{N}, 11.8^{\circ} \mathrm{W}$ ), together with perfluoro-carbon (PFC) tracer gas released over a 2-h period starting at 2200 UTC on 16 July. The balloons were programmed to maintain a constant altitude of $500 \mathrm{~m}$. The balloons maintained this until 19-20 h into the experiment when they failed and rose into the FT. After that detection of the PFC plume was used as evidence for the location of the air parcel trajectory. The cumulative time actually spent within the tagged parcel of air was about $14.5 \mathrm{~h}$, which effectively covered a $29-\mathrm{h}$ period of evolution from start to finish.

The flight pattern (Johnson et al., 2000a) during each sortie took the form of profiles to characterise the vertical properties of the MBL and lower FT, and box patterns consisting of $42 \mathrm{~km}$ legs carried out at levels of interest. The boxes were designed with the purpose of determining divergence and entrainment rates (Sollazzo et al., 2000).

\section{General overview of the air parcel and the aerosol, cloud and MBL development}

Back trajectories (Johnson et al., 2000a; Verver et al., 2000) show that the airmass originated from France and the Iberian peninsula, although there was also evidence that some of the air entrained into the MBL had come from the mid-North Atlantic having not encountered land. The outflow 


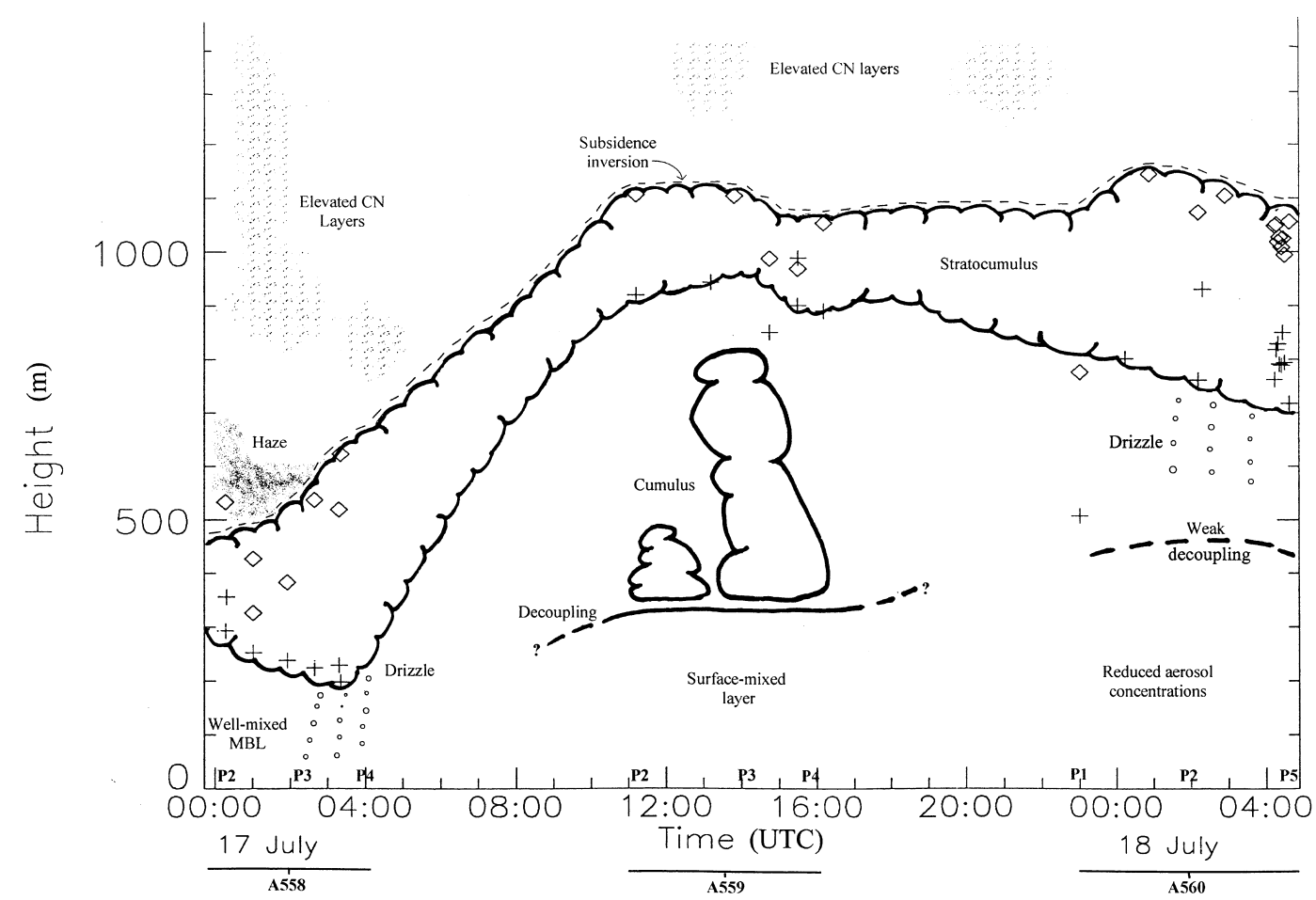

Fig. 1. Schematic diagram of the principal cloud, boundary layer and aerosol evolutionary features that occurred during the Lagrangian of 16-18 July 1997 over the 3 flights A558, A559 and A560 that took place during the night, day and night respectively. The diagram has been based on the observations of cloud top (diamond symbols) and cloud base (plus symbols) of the stratocumulus. $\mathrm{CN}$ stands for condensation nuclei (total particle counts). The profiles (e.g., P2, P3) used in subsequent figures are labelled just above the abscissa.

from Europe was within the eastern flank of the Azores anticyclone that was ridging into northwest Europe. The air parcel is estimated to have been over the ocean for $\sim 12 \mathrm{~h}$, i.e., since leaving the northwestern tip of the Iberian peninsula.

Observations of non-methane hydrocarbons (NMHCs) showed very low mixing ratios (i.e., a few ppt or less) of reactive NMHCs with average atmospheric residence times of a day or less such as xylenes and heavier alkanes. This suggests that the air was significantly aged photochemically (probably by 1 week) since its last contact with such NMHC sources. This indicates a low source of these NMHCs over Iberia, e.g., the air had not recently passed over a major city. At the same time significant amounts (i.e., in general exceeding $10 \mathrm{ppt}$, occasionally even $100 \mathrm{ppt}$ ) of substances such as propane, acetylene, toluene, and butane, which have atmospheric residence times of a few days to about 1 week, were observed. Such values of these NMHCs were on occasion correlated with distinct aerosol layers, consistent with suggesting a continental source of these layers.

The basic evolutionary features of the MBL during the second Lagrangian of ACE-2 is shown by the schematic diagram in Fig. 1. Observations

Fig. 2. Variation of potential temperature $\left(\theta_{\mathrm{v}}\right.$, solid line using the lower abscissa in each plot $)$ and equivalent potential temperature $\left(\theta_{\mathrm{e}}\right.$, dotted line using the upper abscissa in each plot) with height below $2 \mathrm{~km}$ through the Lagrangian of 16-18 July 1997. Three profiles are shown from each flight, A558 on the top row (profiles P2, P3 and P4), A559 on the middle row (P2, P3 and P4), and A560 on the bottom row (P1, P2 and P5). Box-averaged data is also shown by $\theta_{\mathrm{v}}$ using the plus symbols and $\theta_{\mathrm{e}}$ using the triangles, with variability bars representing \pm 1 standard deviation. 
$\theta \quad(K)$

310315320325330

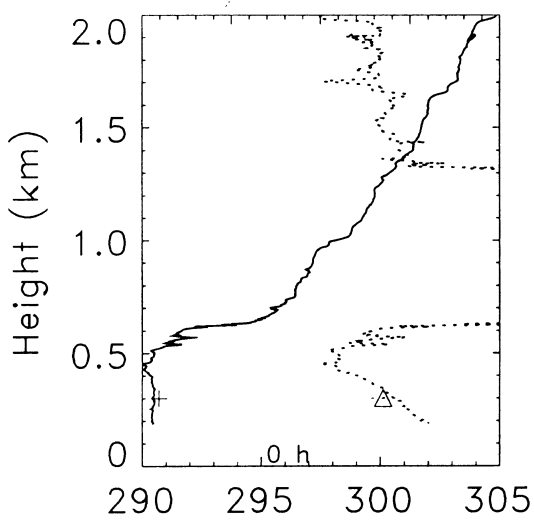

310315320325330

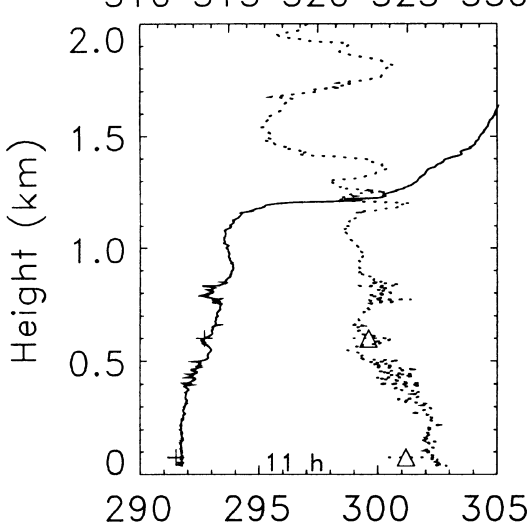

310315320325330

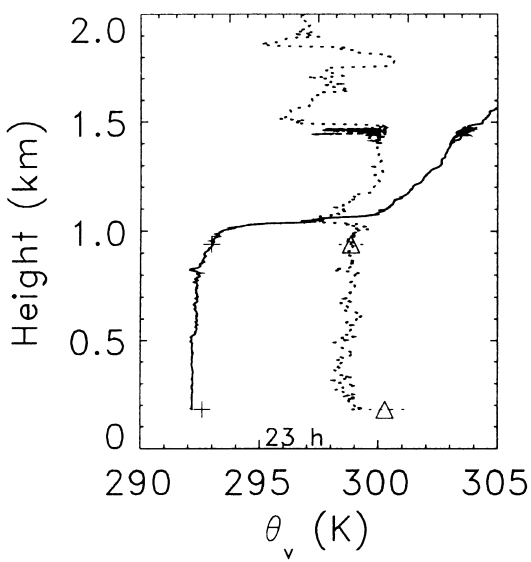

$\theta \quad(K)$
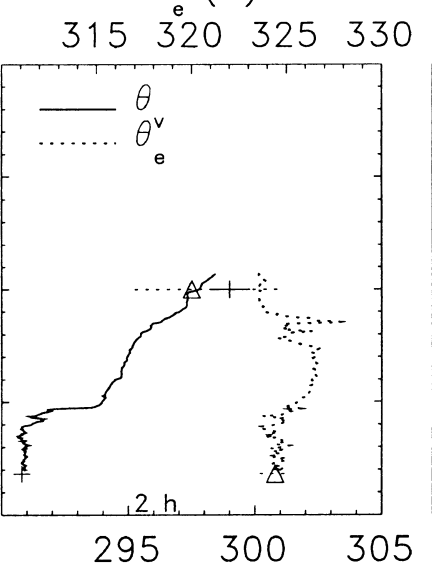

$295300 \quad 305$

$\begin{array}{llll}315 & 320 & 325 & 330\end{array}$

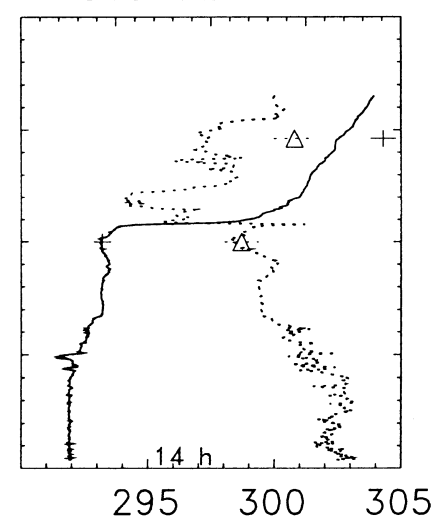

$315 \quad 320 \quad 325 \quad 330$

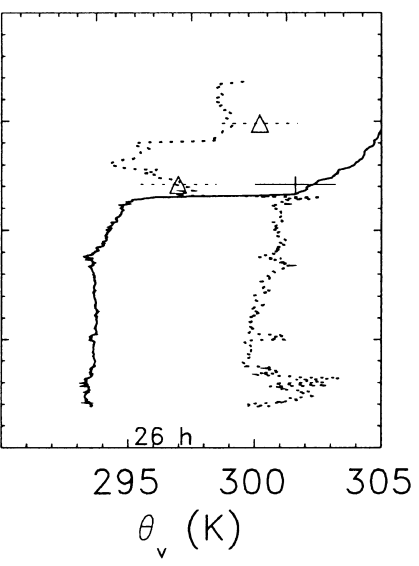

$\theta$ (K)

315320325330

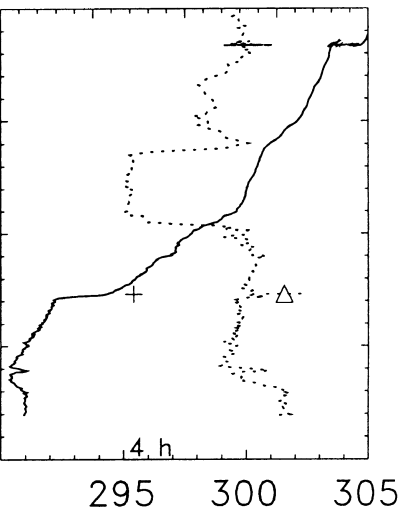

315320325330

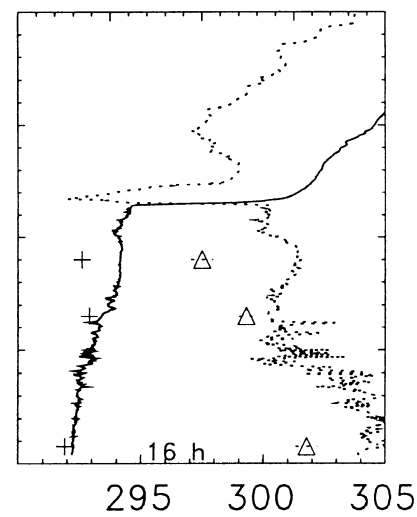

315320325330

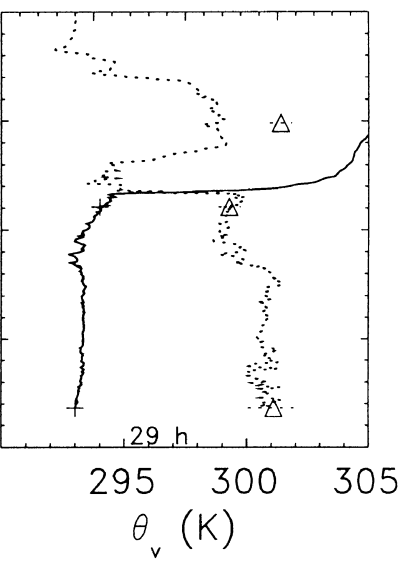

Tellus 52B (2000), 2 
of the variation in the stratocumulus tops and base are included in Fig. 1. This schematic diagram serves only as a rough sketch of the main features and changes observed and should be viewed in the context of the figures and text to follow in subsequent sections.

The balloons were positioned in the MBL and, since the winds above the MBL can be differential with height through the inversion, no evolutionary conclusions can be drawn from measurements above the MBL. During flight A558, the residual continental boundary layer was initially observed from the surface up to a height of $2 \mathrm{~km}$. The stratocumulus layer was very low with cloud base at $300 \mathrm{~m}$ and cloud tops maintained at $500 \mathrm{~m}$ by a subsidence inversion and hydrolapse. The MBL was well-mixed up to the cloud top such that the aerosol microphysics was uniform with height below cloud base. Very high loadings of aerosol were observed in a 200-400 $\mathrm{m}$ deep layer just above cloud top (in an elevated pollution layer or EPL) during the first $3 \mathrm{~h}$ of the experiment, which was entrained into the MBL by $4 \mathrm{~h}$ into the period. This entrainment modified the cloud and aerosol microphysics in the MBL. Other EPLs (mainly of Aitken mode aerosol) were observed on occasions through the experiment. Significant drizzle drops were observed below cloud base between $2-4 \mathrm{~h}$ into the experiment, where the cloud had thickened to its maximum depth during the experiment. Surface wetness detection on the smart balloons suggests that both balloons were within cloud during the first $6 \mathrm{~h}$ or so of the Lagrangian.

Between flights A558 and A559 the MBL had grown to over $1000 \mathrm{~m}$. The MBL was decoupled during the day, with the surface-mixed layer (SML) being conditionally unstable where cumulus cells were growing from about $500 \mathrm{~m}$. A small proportion of these were penetrating the stratocumulus layer, which had thinned compared to flight A558 presumably due to a reduction in surface fluxes reaching the cloud layer. This was enough to cause the cloud to just break, but still maintain $90 \%$ or more coverage. Drizzle rates were very low during the daytime. The decoupling affected the vertical structure of the MBL in terms of aerosol and trace gases, as well as the dynamics and thermodynamics.

During A560, the stratocumulus top was at about the same height as A559, with the cloud thickening again and producing the highest observed drizzle liquid water, but none was reaching the surface. The subsidence inversion intensified through the experiment and the air above the inversion was drier in A560 than it had been earlier during the day. The MBL was relatively well-mixed as regards aerosol and trace gas profiles compared to flight A559, although it is believed that cumulus clouds were occasionally penetrating the stratocumulus based on in-cloud measurements. Both accumulation and Aitken mode aerosol concentrations reduced gradually through A559 and A560, while the cloud droplet concentration gradually increased.

\section{Thermodynamic and dynamic evolution of the boundary layer}

\subsection{Potential temperature and equivalent potential temperature}

Fig. 2 shows all available soundings (three per flight) of potential temperature $\left(\theta_{\mathrm{v}}\right)$ and equivalent potential temperature $\left(\theta_{\mathrm{e}}\right)$ from profiles below $2 \mathrm{~km}$ covering the MBL and lower FT. The profiles from A558 and A560 only go down to an altitude of $\sim 180 \mathrm{~m}$ due to restrictions of flying at night. Mean values with variability bars of one standard deviation* $(\sigma)$ from the box patterns (i.e., approximately $30 \mathrm{~min}$ of data) have also been included.

The depth of the MBL (based on the inversion of $\theta_{\mathrm{v}}$ with height) decreases from $600 \mathrm{~m}$ to $450 \mathrm{~m}$ during the first few hours of A558, but then grows by the end of A558 to $700 \mathrm{~m}$. The increase in $\theta_{\mathrm{e}}$ at the bottom of profile P4 at the end of A558 (of 2-3 K) maybe indicative of the MBL starting to decouple and moisture building up in the lower layer in direct contact with the sea surface. Such a change in the MBL structure at night could be induced by sea surface fluxes or by drizzle evaporation. Changes in $\theta_{\mathrm{e}}$ of $2-3 \mathrm{~K}$ have been shown to be significant in thermodynamic terms (Nicholls, 1984).

There is a more significant growth of the MBL between 0400 and 1100 UTC from $700 \mathrm{~m}$ to $1200 \mathrm{~m}$ while the inversion in $\theta_{\mathrm{v}}$ intensified from

* One standard deviation from the mean of any measurable will hereafter be denoted by the letter $\sigma$. 
$\sim 2.5 \mathrm{~K}$ to $\sim 10 \mathrm{~K}$ and the air above the inversion became drier, as seen by the reduction in $\theta_{\mathrm{e}}$ in profiles P3 and P4 during A559. The MBL was decoupled during the daytime at $500 \mathrm{~m}$ as can be seen by an increase in $\theta_{\mathrm{e}}$ of $4-5 \mathrm{~K}$ in the SML. This is substantiated by the box-pattern averages shown by the triangle symbols. This decoupling was also seen in the total water content where the moisture was higher in the SML than the cumulus layer by $\geqslant 2 \mathrm{~g} \mathrm{~kg}^{-1}$.

During A560 on 18 July 1997 the MBL was still over $1 \mathrm{~km}$ deep while the inversion intensified to $\sim 13 \mathrm{~K}$ by the end of the experiment and the air just above the inversion had dried out even more. The relative humidity of the un-polluted lower FT decreased from $85.2 \pm 5.1 \%$, to $84.1 \pm 2.0 \%$, to $79.2 \pm 0.6 \%$ through the 3 flights. The MBL seems to have re-coupled based on the vertical profiles of $\theta_{\mathrm{e}}$ during A560 where values were similar to those at the start of the experiment. However, the box-averaged values of $\theta_{\mathrm{e}}$ show a small but consistent increase (of 2-2.5 K) at $200 \mathrm{~m}$ compared to within the cloud layer.

\subsection{Decoupling of the $M B L$}

The rate of increase in the height of the inversion between $4-11 \mathrm{~h}$ into the experiment is equivalent to an entrainment rate of $1.7 \mathrm{~cm} \mathrm{~s}^{-1}$, i.e., rapid but not unrealistic. The effect of FT subsidence would increase this value even further. Indeed, Sollazzo et al. (2000) show that entrainment during this period actually peaked at $2.3 \mathrm{~cm} \mathrm{~s}^{-1}$. While the MBL was deepening, the MBL probably decoupled by one or more of (i) radiative means (due to short-wave absorption), (ii) evaporative cooling of drizzle drops perturbing the temperature and moisture structure, or (ii) a "warmingdeepening" effect as the sea-surface temperature (SST) increased which is independent of diurnal decoupling (Bretherton and Wyant, 1997). It is thought that the observed increase in SST of less than $1 \mathrm{~K}$ over the $\sim 7$-h period cannot alone account for the increase in cloud top height by increased surface fluxes, all other fluxes being constant with time. (The initial SST was $292.8 \pm 0.12 \mathrm{~K}$, which compared favourably with the RV Vodyanitskiy measurement of $292.5 \pm 0.07 \mathrm{~K}$.) This presumption is based on the simulations of Bretherton and Wyant (1997) within cloud-topped sub-tropical regions where a similar increase in height was due to SST increases of $6 \mathrm{~K}$ or more. The increase in SST over this experiment was $\sim 1.8 \mathrm{~K}$ which is not a large gradient over the distance covered of about $1000 \mathrm{~km}$. With Bretherton and Wyant assuming that the FT structure remained relatively unchanged, the observed height increase could therefore be aided by a change in the subsidence rate in the FT whereby a reduction could then have allowed the surface fluxes to raise the inversion height.

As the MBL grew, turbulent kinetic energy generated by the radiative cooling at cloud top was probably not enough to over-turn the now deeper layer and so the surface fluxes dominated up to a certain height and the MBL became driven by the two separate circulations, although mixing seems to be fairly significant between them. The decoupling was also evident when looking at trace gases such as inorganic peroxide (Fig. 4). The general upward trend of $\mathrm{H}_{2} \mathrm{O}_{2}$ with height through the experiment is to be expected and is a strong function of deposition to the sea surface. Within the decoupled MBL during A559 (particularly in P4), the $\mathrm{H}_{2} \mathrm{O}_{2}$ values dropped off within the SML.

Overnight again, radiative cooling at cloud top becomes more dominant and so re-coupling (to at least some degree) would be expected to occur via stronger radiatively-driven turbulent overturning of the MBL during flight A560. However, there were a few occasions when flying in cloud during A560 where evidence for cumulus penetration was found. Broad updraughts over $700 \mathrm{~m}$ wide were observed within which peaks in vertical velocity of over $3 \mathrm{~m} \mathrm{~s}^{-1}$ were measured. Correlations were also observed in $q_{\mathrm{L}}$ (up to $0.3 \mathrm{~g} \mathrm{~m}^{-3}$ above the ambient stratocumulus values), the cloud droplet concentration $N_{\mathrm{d}}$ (up to $100 \mathrm{~cm}^{-3}$ above ambient values due presumably to a greater peak supersaturation at cloud base), and $\theta_{\mathrm{e}}$ (up to $3 \mathrm{~K}$ above ambient values because of the convection of warmer, moister air from the SML into the cloud layer). The higher values of $q_{\mathrm{L}}$ indicate that the cloud base of the cumulus were below that of the overlying stratocumulus. Even though vertical evolution in cumulus cells is non-adiabatic (even in the core) due to high entrainment rates, it is feasible to estimate a minimum distance between the stratocumulus and cumulus bases using a linear assumption of the increase in $q_{\mathrm{L}}$ with height that is the same in both 
Table 2. Summary from the box patterns within the MBL and lower FT at the time since the start of the experiment in hours of: $\mathrm{SO}_{2}$ mixing ratio; mean accumulation mode aerosol concentration $\left(\mathrm{N}_{a}\right)$; mean $\mathrm{CN}$ concentration; mean wind speed $(\bar{U})$; mean wind direction $(\phi)$ in degrees from north; mean cloud droplet concentration $\left(N_{d}\right)$; and the measured CCN concentration at $0.2 \%$ supersaturation

\begin{tabular}{|c|c|c|c|c|c|c|c|c|c|}
\hline Layer & $\begin{array}{l}\text { Time } \\
\text { (h) }\end{array}$ & $\begin{array}{l}\text { Height } \\
(\mathrm{m})\end{array}$ & $\begin{array}{l}\mathrm{SO}_{2} \\
\text { (ppt) }\end{array}$ & $\begin{array}{c}N_{\mathrm{a}} \\
\left(\mathrm{cm}^{-3}\right)\end{array}$ & $\begin{array}{c}\mathrm{CN} \\
\left(\mathrm{cm}^{-3}\right)\end{array}$ & $\begin{array}{c}\bar{U} \\
\left(\mathrm{~m} \mathrm{~s}^{-1}\right)\end{array}$ & $\begin{array}{c}\phi \\
(\mathrm{deg})\end{array}$ & $\begin{array}{c}N_{\mathrm{d}} \\
\left(\mathrm{cm}^{-3}\right)\end{array}$ & $\begin{array}{c}\mathrm{CCN} 0.2 \% \\
\left(\mathrm{~cm}^{-3}\right)\end{array}$ \\
\hline \multicolumn{10}{|c|}{ Flight A558 } \\
\hline $\mathrm{SCU}$ & 0.5 & 295 & - & - & - & $\begin{array}{c}12.8 \\
{[0.9]}\end{array}$ & $\begin{array}{c}10.4 \\
{[6.3]}\end{array}$ & $\begin{array}{c}203 \\
{[37]}\end{array}$ & - \\
\hline LFT & 1.0 & 1080 & $\begin{array}{c}35 \\
{[11]}\end{array}$ & $\begin{array}{c}201 \\
{[80]}\end{array}$ & $\begin{array}{c}3473 \\
{[793]}\end{array}$ & $\begin{array}{c}9.8 \\
{[1.6]}\end{array}$ & $\begin{array}{c}19.4 \\
{[6.8]}\end{array}$ & - & 115 \\
\hline SML & 2.0 & 230 & $\begin{array}{c}\mathbf{8 0 0} \\
{[57]}\end{array}$ & $\begin{array}{c}910 \\
{[206]}\end{array}$ & $\begin{array}{c}3389 \\
{[599]}\end{array}$ & $\begin{array}{c}11.0 \\
{[1.0]}\end{array}$ & $\begin{array}{c}15.6 \\
{[10.0]}\end{array}$ & - & 260 \\
\hline EPL & 3.2 & 750 & $\begin{array}{l}760 \\
{[55]}\end{array}$ & $\begin{array}{c}1004 \\
{[631]}\end{array}$ & $\begin{array}{c}6416 \\
{[2449]}\end{array}$ & $\begin{array}{c}9.5 \\
{[1.2]}\end{array}$ & $\begin{array}{l}28.1 \\
{[5.8]}\end{array}$ & - & 295 \\
\hline \multicolumn{10}{|c|}{ Flight A559 } \\
\hline SML & 12.0 & 85 & $\begin{array}{c}\mathbf{2 1 0} \\
{[21]}\end{array}$ & $\begin{array}{c}928 \\
{[166]}\end{array}$ & $\begin{array}{c}\mathbf{2 8 8 9} \\
{[1099]}\end{array}$ & $\begin{array}{c}\mathbf{5 . 4} \\
{[1.5]}\end{array}$ & $\begin{array}{c}\mathbf{5 2 . 3} \\
{[69.8]}\end{array}$ & - & 355 \\
\hline $\mathrm{CU}$ & 12.6 & 630 & $\begin{array}{c}61 \\
{[17]}\end{array}$ & $\begin{array}{c}745 \\
{[181]}\end{array}$ & $\begin{array}{c}2193 \\
{[504]}\end{array}$ & $\begin{array}{c}7.5 \\
{[1.3]}\end{array}$ & $\begin{array}{c}29.4 \\
{[10.3]}\end{array}$ & - & 350 \\
\hline SCU & 13.5 & 1010 & - & - & - & $\begin{array}{c}3.7 \\
{[1.3]}\end{array}$ & $\begin{array}{c}52.0 \\
{[92.6]}\end{array}$ & $\begin{array}{c}187 \\
{[50]}\end{array}$ & - \\
\hline LFT & 14.3 & 1670 & $\begin{array}{c}9 \\
{[16]}\end{array}$ & $\begin{array}{c}184 \\
{[57]}\end{array}$ & $\begin{array}{c}853 \\
{[465]}\end{array}$ & $\begin{array}{c}7.0 \\
{[0.8]}\end{array}$ & $\begin{array}{c}39.7 \\
{[13.4]}\end{array}$ & - & 130 \\
\hline SML & 15.0 & 85 & $\begin{array}{c}79 \\
{[11]}\end{array}$ & $\begin{array}{c}744 \\
{[109]}\end{array}$ & $\begin{array}{c}2019 \\
{[290]}\end{array}$ & $\begin{array}{c}\mathbf{9 . 6} \\
{[1.1]}\end{array}$ & $\begin{array}{c}11.2 \\
{[4.4]}\end{array}$ & - & 440 \\
\hline SCU & 15.5 & 990 & - & - & - & $\begin{array}{c}8.5 \\
{[1.3]}\end{array}$ & $\begin{array}{l}298.8 \\
{[5.1]}\end{array}$ & $\begin{array}{c}196 \\
{[42]}\end{array}$ & - \\
\hline $\mathrm{CU}$ & 16.0 & 785 & - & $\begin{array}{c}565 \\
{[90]}\end{array}$ & $\begin{array}{c}1576 \\
{[195]}\end{array}$ & $\begin{array}{c}7.5 \\
{[0.7]}\end{array}$ & $\begin{array}{c}32.0 \\
{[85.0]}\end{array}$ & - & - \\
\hline \multicolumn{10}{|c|}{ Flight $\mathbf{A 5 6 0}$} \\
\hline SML & 24.0 & 180 & $\begin{array}{c}\mathbf{1 4} \\
{[11]}\end{array}$ & $\begin{array}{c}\mathbf{6 0 3} \\
{[82]}\end{array}$ & $\begin{array}{c}\mathbf{1 5 1 3} \\
{[223]}\end{array}$ & $\begin{array}{c}\mathbf{8 . 8} \\
{[1.2]}\end{array}$ & $\begin{array}{c}14.1 \\
{[7.8]}\end{array}$ & - & 300 \\
\hline $\mathrm{SCU}$ & 24.5 & 940 & - & - & - & $\begin{array}{c}8.3 \\
{[1.4]}\end{array}$ & $\begin{array}{c}29.0 \\
{[7.4]}\end{array}$ & $\begin{array}{c}217 \\
{[44]}\end{array}$ & - \\
\hline LFT & 25.0 & 1210 & $\begin{array}{c}5 \\
{[18]}\end{array}$ & $\begin{array}{c}290 \\
{[130]}\end{array}$ & $\begin{array}{c}868 \\
{[269]}\end{array}$ & $\begin{array}{c}9.7 \\
{[0.2]}\end{array}$ & $\begin{array}{c}40.8 \\
{[2.5]}\end{array}$ & - & 230 \\
\hline LFT & 26.0 & 1695 & $\begin{array}{c}12 \\
{[19]}\end{array}$ & $\begin{array}{c}301 \\
{[84]}\end{array}$ & $\begin{array}{c}897 \\
{[156]}\end{array}$ & $\begin{array}{c}6.5 \\
{[1.1]}\end{array}$ & $\begin{array}{c}25.2 \\
{[7.5]}\end{array}$ & - & 180 \\
\hline $\mathrm{SCU}$ & 26.5 & 1105 & - & - & - & $\begin{array}{c}7.8 \\
{[1.4]}\end{array}$ & $\begin{array}{c}30.6 \\
{[14.3]}\end{array}$ & $\begin{array}{c}242 \\
{[47]}\end{array}$ & - \\
\hline LFT & 27.5 & 1710 & $\begin{array}{c}26 \\
{[13]}\end{array}$ & $\begin{array}{c}287 \\
{[72]}\end{array}$ & $\begin{array}{c}863 \\
{[118]}\end{array}$ & $\begin{array}{c}6.3 \\
{[1.3]}\end{array}$ & $\begin{array}{c}14.8 \\
{[9.1]}\end{array}$ & - & 200 \\
\hline SML & 28.0 & 180 & $\begin{array}{c}\mathbf{4 2} \\
{[10]}\end{array}$ & $\begin{array}{c}618 \\
{[100]}\end{array}$ & $\begin{array}{c}\mathbf{1 5 5 8} \\
{[433]}\end{array}$ & $\begin{array}{c}\mathbf{8 . 3} \\
{[1.0]}\end{array}$ & $\begin{array}{c}\mathbf{1 8 . 5} \\
{[14.8]}\end{array}$ & - & 300 \\
\hline
\end{tabular}

All the errors (printed on the line below the mean values) show one standard deviation except (i) the $\mathrm{SO}_{2}$ error which is the greater of either $6 \%$ of the measured value (i.e., the analytical error in the measurement technique) or twice the standard deviation of the associated blank control filter; and (ii) the CCN error which is not shown but the variability is typically $<40 \%$ (Figs. 12 and 13 ). $\mathrm{SO}_{2}$ concentrations have been analysed from impregnated filter samples. The different layers are surface-mixed layer (SML), lower free troposphere (LFT), cumulus (CU) layer, stratocumulus (SCU) layer, and elevated pollution layer (EPL). 


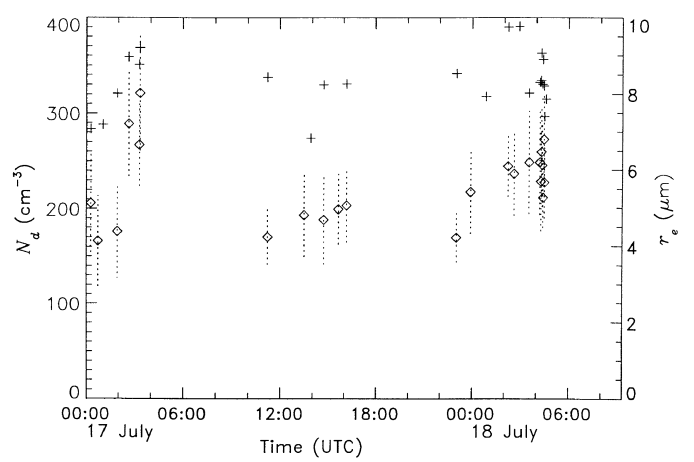

Fig. 3. Time series variation of the stratocumulus cloud droplet concentration (diamond symbols, using the lefthand ordinate) with variability bars of \pm 1 standard deviation and cloud top droplet effective radius (crosses, using the right-hand ordinate) from the Lagrangian between 16-18 July 1997. The droplet concentrations are from boxes and profiles, while the effective radii are from profiles only.

the stratocumulus and cumulus. This shows that the cumulus base was at least $150 \mathrm{~m}$ below that of the stratocumulus during A560.

\subsection{Boundary layer winds}

The RV Vodyanitskiy measured wind speeds of $10.4 \pm 0.6 \mathrm{~m} \mathrm{~s}^{-1}$ at the start of the Lagrangian. Aircraft-observed wind speed and direction averaged over box patterns are displayed in Table 2 . Within the SML, they were highest at the start of the Lagrangian at $11.0 \pm 1.0 \mathrm{~m} \mathrm{~s}^{-1}$ (the mean and $\sigma$ at $180 \mathrm{~m}, 2 \mathrm{~h}$ into the experiment where peak values reached $15.3 \mathrm{~m} \mathrm{~s}^{-1}$ ), reducing to a minimum of $5.4 \pm 1.5 \mathrm{~m} \mathrm{~s}^{-1}$ (at $80 \mathrm{~m}, 12 \mathrm{~h}$ into the period), recovering to $9.6 \pm 1.1 \mathrm{~m} \mathrm{~s}^{-1}$ (at $80 \mathrm{~m}$, $15 \mathrm{~h}$ from the start), and then decreasing to $8.3 \pm 1.0 \mathrm{~m} \mathrm{~s}^{-1}$ (at $180 \mathrm{~m}, 28 \mathrm{~h}$ into the period) These measurements generally lie within $1.5 \mathrm{~m} \mathrm{~s}^{-1}$ of both the ECMWF analyses winds and the balloon-derived winds (based on the relative GPS motion of the balloons with time)

Within the MBL during A558 the shear in wind speed was no greater than $2 \mathrm{~m} \mathrm{~s}^{-1} \mathrm{~km}^{-1}$. Between 12-14 h into the experiment during A559, the vertical wind shear approached $7 \mathrm{~m} \mathrm{~s}^{-1} \mathrm{~km}^{-1}$ within the MBL. This implies that the differential motion of the air over this period was comparable to the dimensions of the box patterns and thus probably not too significant in terms of varying the origins of the air in the tagged column of air. Apart from this relatively short period, wind shear between the surface and the inversion during the rest of A559 and A560 was generally less than $3 \mathrm{~m} \mathrm{~s}^{-1} \mathrm{~km}^{-1}$ and mostly less than $2 \mathrm{~m} \mathrm{~s}^{-1} \mathrm{~km}^{-1}$.

The value of $\sigma$ of vertical velocity measured throughout whole box patterns within the layer of stratocumulus increased from $0.34 \mathrm{~m} \mathrm{~s}^{-1}$ in A558, to $0.48 \mathrm{~m} \mathrm{~s}^{-1}$ in $\mathrm{A} 559$, and to $0.55 \mathrm{~m} \mathrm{~s}^{-1}$ in A560.

\section{Cloud physics evolution}

\subsection{Droplet concentrations and effective radii}

Table 2 shows box-averaged values of $N_{\mathrm{d}}$ and associated $\sigma$ variability within the stratocumulus. Values were highest towards the end of A560 and lowest (but most variable) in A559. The resolution of these values is rather low and so Fig. 3 shows the variation in $N_{\mathrm{d}}$ and cloud top droplet effective radius* $\left(r_{\mathrm{e}}\right)$ measured during all profiles and box patterns throughout the Lagrangian as a function of time, together with variability bars of $\pm \sigma$. Note the large increase in $N_{\mathrm{d}}$ towards the end of flight A558, accompanied by an increase in $r_{\mathrm{e}}$. These increases coincide with the concurrent thickening of the cloud layer (Fig. 1). The increase in $N_{\mathrm{d}}$ at the end of A558 was not accompanied by an increase in the observed vertical air velocity such that the cause is likely to be an increase in available CCN. This reasoning is explored further later on.

There was a gradual increase in $N_{\mathrm{d}}$ (at an average rate of $59 \% \mathrm{day}^{-1}$ ) over the last $18 \mathrm{~h}$ of the period. $r_{\mathrm{e}}$ was variable during flights A559 and A560, although a little higher on average during the last flight; these variations reflect the variations in cloud thickness, in that a thicker cloud will have a greater $q_{\mathrm{L}}$ and hence larger droplet sizes. The drop in $N_{\mathrm{d}}$ of more than a third between the end of A558 and the start of A559 was probably principally due to the expansion of the MBL and hence dilution of the aerosol and hence available $\mathrm{CCN}$. The increase in the MBL depth from $700 \mathrm{~m}$ to $1100 \mathrm{~m}$ (a $57 \%$ increase) is a little higher than

* The effective radius is defined here as in Hansen (1971), i.e., the ratio of the third moment to the second moment of the size distribution of an ensemble of particles. 

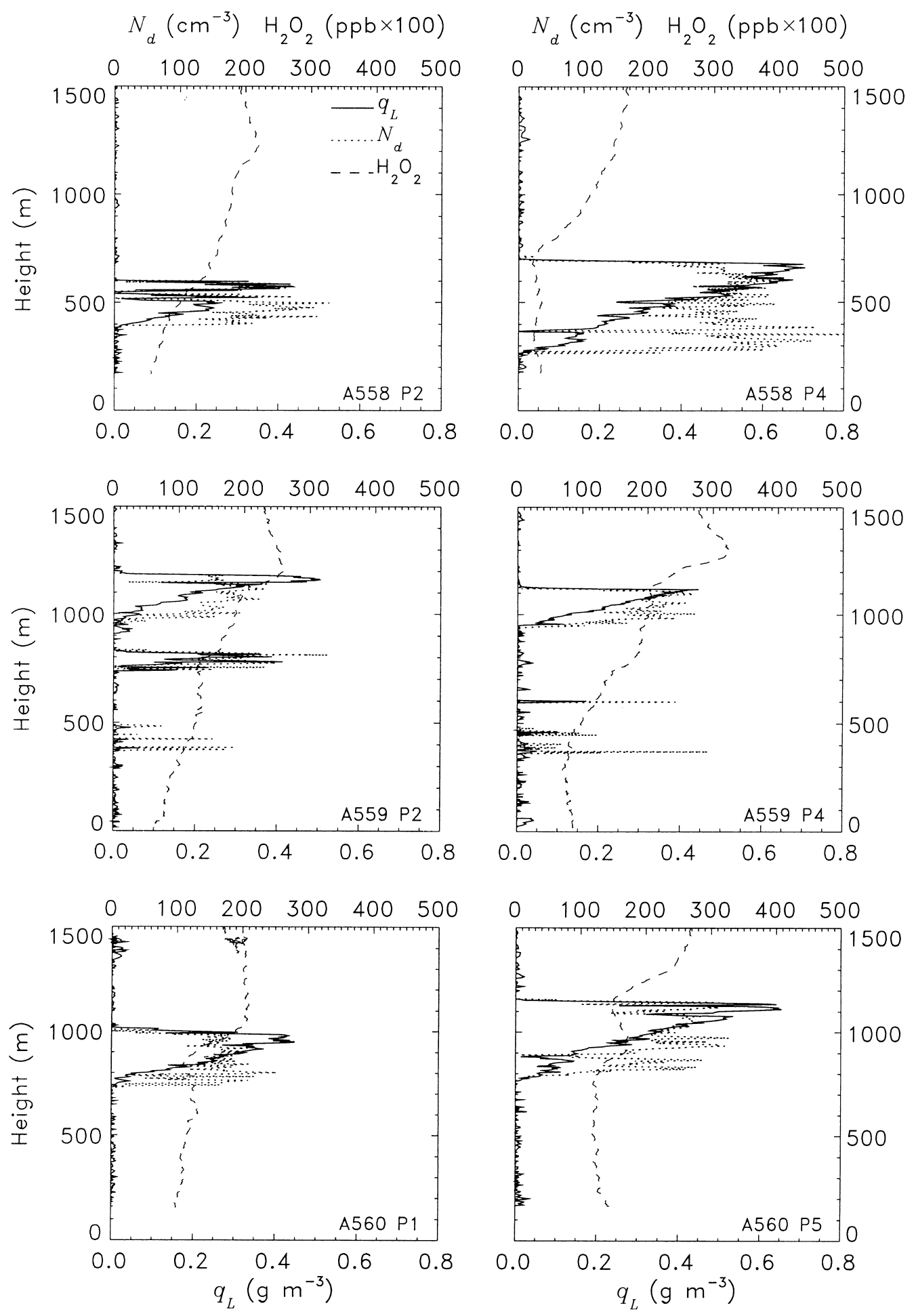

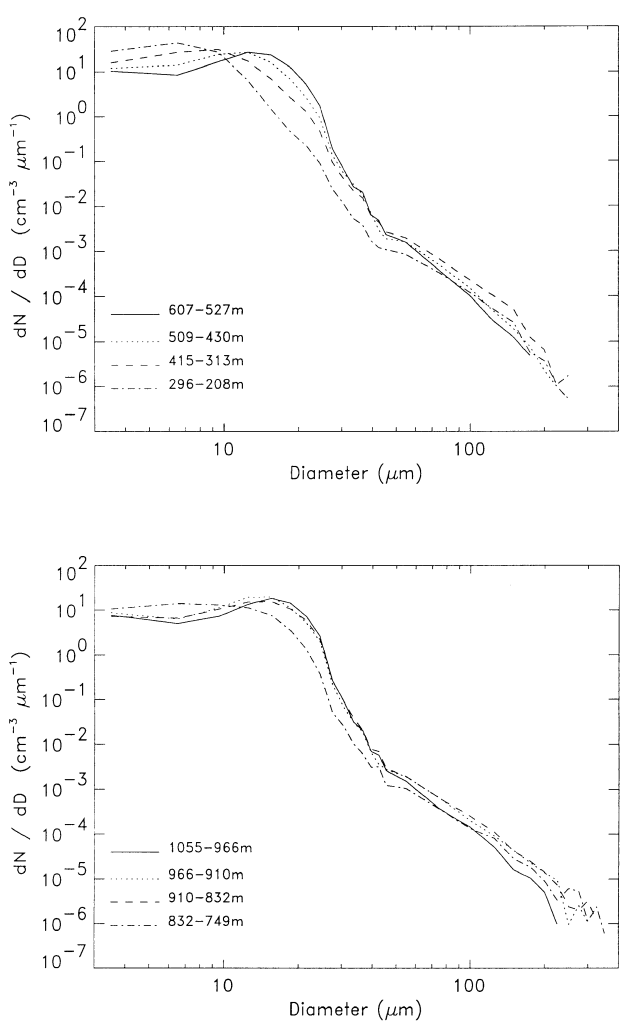

Fig. 5. Cloud droplet-size distributions using both FSSP and 2-DC data from (a) A558 (profile P4 on 17 July 1997), and (b) A560 (profile P5 on 18 July 1997). Each set of spectra was measured from a profile through the stratocumulus and show the variation with height in the layer; the height intervals over which each spectrum is averaged are given in the key. In the overlap of the size range of each probe, the data have been averaged

the reduction in $N_{\mathrm{d}}$ from $300 \mathrm{~cm}^{-3}$ to $170 \mathrm{~cm}^{-3}$ (a $43 \%$ decrease), such that the dilution may have been offset by the increase in the vertical wind speed.

\subsection{Vertical structure of $q_{L}$ and $N_{d}$}

The evolution of the cloud layer in terms of $q_{\mathrm{L}}$ and $N_{\mathrm{d}}$ is shown in the series of six profiles in (a) Fig. 4. The increase in cloud top height between A558 and A559 is quite marked, with an associated decrease in cloud thickness from about $400 \mathrm{~m}$ to $200 \mathrm{~m} . q_{\mathrm{L}}$ is highest where the cloud is thickest in A558, with cloud top values of $0.7 \mathrm{~g} \mathrm{~m}^{-3}$. The profiles of $q_{\mathrm{L}}$ are generally reasonably linear with height, although they are generally sub-adiabatic at rates of about $1.7 \mathrm{~g} \mathrm{~m}^{-3} \mathrm{~km}^{-1}$ except for profile P4 during A559 where the rate was over $2 \mathrm{~g} \mathrm{~m}^{-3} \mathrm{~km}^{-1}$ and hence close to adiabatic. The vertical structure of $N_{\mathrm{d}}$ within the stratocumulus is reasonably constant which implies there was little erosion by entrainment of FT air at cloud top.

$N_{\mathrm{d}}$ was highest at the very end of A558, where values averaged $330 \mathrm{~cm}^{-3}$, with one peak of $600 \mathrm{~cm}^{-3} . N_{\mathrm{d}}$ reduced again in flight A559 (down to $\left.200-230 \mathrm{~cm}^{-3}\right)$, but increased during the last flight (between $200-300 \mathrm{~cm}^{-3}$ ). Cumulus cloud penetrations can be seen below the stratocumulus in flight A559 in Fig. 4, where peak values of $N_{\mathrm{d}}$ in the cumulus cells were higher (over $300 \mathrm{~cm}^{-3}$ ) than the overlying stratocumulus $\left(\sim 230 \mathrm{~cm}^{-3}\right)$. Values of $N_{\mathrm{d}}$ within the stratocumulus layer during A559 where cumulus cells were penetrating the layer when measured in a box pattern near the cloud tops peaked over $400 \mathrm{~cm}^{-3}$. During A560, $N_{\mathrm{d}}$ approached $400 \mathrm{~cm}^{-3}$ within cumulus penetrations during the box patterns.

\subsection{Droplet spectra and drizzle}

Fig. 5 shows how the cloud droplet-size distribution varied between flights A558 and A560. There was a shift in the modal diameter to slightly larger sizes and the drizzle mode* was significantly more developed in the last flight, with drops reaching $300 \mu \mathrm{m}$ in diameter. The $2 \mathrm{D}-\mathrm{C}$ measured drizzle drops in fairly significant concentrations during flight A558 below cloud base and so washout may

* It is assumed here that a drizzle drop is one formed by one or more coalescence events of cloud droplets, and is therefore not necessarily related to precipitation falling below cloud base.

Fig. 4. A series of six profiles below $1.5 \mathrm{~km}$ from the Lagrangian between 16-18 July 1997 showing liquid water content $\left(q_{\mathrm{L}}\right.$; solid line using the lower abscissa in each profile plot) cloud droplet concentration $\left(N_{\mathrm{d}}\right.$; dotted line using the upper abscissa in each profile plot), and inorganic peroxide $\left(\mathrm{H}_{2} \mathrm{O}_{2}\right.$; dashed line using the upper abscissa where the data in ppb has been multiplied by 100). Two profiles have been used from each flight: P2 and P4 from A558, P2 and P4 from A559, and P1 and P5 from A560 as labelled on the individual plots. The profiles coincide roughly with the start and end times of the flights given in Table 1.

Tellus 52B (2000), 2 
have occurred in the early part of the Lagrangian. The thin stratocumulus during A559 produced no drizzle below cloud base. No precipitation was observed during box patterns during A560 at $200 \mathrm{~m}$ altitude.

Precipitation rates have been estimated by calculating the size distribution of drops reaching the sea surface based on the measured distribution leaving cloud base, the measured relative humidity profile below cloud base, evaporation rates of the drops, and the terminal velocity as a function of drop size. Where the cloud was thickest (and lowest in height) at the end of flight A558, the precipitation rate at cloud base has been estimated at $39.4 \mathrm{~g} \mathrm{~m}^{-2} \mathrm{~s}^{-1}$, of which $12 \% \mathrm{day}^{-1}$ has been estimated to have reached the sea surface at that time. During A560, where the cloud was thinner than during A558, the precipitation rate at cloud base was higher at $85.3 \mathrm{~g} \mathrm{~m}^{-2} \mathrm{~s}^{-1}$; yet because of the deeper boundary layer none of the drizzle was reaching the surface and so no aerosol was removed by wet deposition. The thinner cloud in A560 produced more drizzle than during A558 because of the droplet condensation mode was situated at a larger size in A560 and was therefore inductive to more efficient droplet coalescence.

The aerosol loss rate has also been crudely estimated using the assumptions that: (i) the cloud droplets formed on the largest accumulation mode particles; (ii) all cloud droplets have the same size $r_{\mathrm{v}}^{\mathrm{FSSP}}$ (calculated from the mean volume radius of the FSSP droplet spectra) and all drizzle drops have the same size $r_{\mathrm{v}}^{2 \mathrm{DC}}$ (calculated from the mean volume radius of the 2-DC spectra) such that the number of $\mathrm{CCN}$ within the drizzle drops is $\left(r_{\mathrm{v}}^{2 \mathrm{DC}} / r_{\mathrm{v}}^{\mathrm{FSSP}}\right)^{3}$ (typical values lay between $20-90$ during A558 and A560); and (iii) all the particles are purely ammonium sulphate.

This implies that $8 \% \mathrm{day}^{-1}$ of the aerosol number and $13 \%$ day $^{-1}$ of the aerosol mass was lost to the surface under the conditions during A558. This shows that even where a low cloud layer is producing significant drizzle, the washout rate is low. That said, the cooling effect produced by the evaporating drizzle drops has been estimated as quite substantial $\left(\sim 7 \mathrm{~K} \mathrm{day}^{-1}\right)$ and so further work is required to ascertain the potential effect this cooling (and associated moistening) would have on the stability and circulation of the MBL. Even though washout was a very slow process, the effect of coalescence on the residual
$\mathrm{CCN}$ concentration cannot be readily ignored, especially where $q_{\mathrm{L}}$ was greater than $0.5 \mathrm{~g} \mathrm{~m}^{-3}$ during A558. The existence of a drizzle mode is evidence that $\mathrm{CCN}$ are effectively combining to form larger particles of lower number concentration.

\section{Aerosol particle and pollution evolution}

\subsection{Bulk aerosol and trace gas concentrations}

Table 2 shows box-averaged accumulation mode aerosol $\left(N_{\mathrm{a}}\right), \mathrm{CN}$ and $\mathrm{SO}_{2}$ concentrations within the MBL and lower FT. CN concentrations (over the same size interval as the C-130 3025 instrument) measured aboard the RV Vodyanitskiy during the balloon and tracer release averaged $2700 \pm 720 \mathrm{~cm}^{-3}$, which is slightly less than SML concentrations initially measured with the aircraft. In A558, higher concentrations of both $\mathrm{CN}$ and $N_{\text {a }}$ (but especially $\mathrm{CN}$ ) were seen in the EPL relative to the SML. The aerosol concentrations were also particularly heterogeneous in the EPL. Comparable mixing ratios of $\mathrm{SO}_{2}$ (of around $800 \mathrm{ppt}$ ) were observed in the SML and EPL during A558. In A559, both $\mathrm{CN}$ and $N_{\mathrm{a}}$ reduce with time in the SML and cumulus layer. In addition the aerosol concentrations were consistently lower in the cumulus layer than the SML. The $\mathrm{SO}_{2}$ values reduced markedly between A558 and A559, and continued to reduce into A560. $\mathrm{SO}_{2}$ was also reduced within the cumulus layer in A559 compared to the SML.

Deposition velocities of $\mathrm{SO}_{2}$ to the sea surface are approximately $1 \mathrm{~mm} \mathrm{~s}^{-1}$ (Hannah Richer, personal communication, 1999) which implies a loss rate of $5.8 \mathrm{ppt} \mathrm{h}^{-1}$ during the first few hours of the period where the MBL was shallow and $\mathrm{SO}_{2}$ mixing ratios were highest. Considering the increase in the MBL depth and the much lower mixing ratios later on produced primarily through dilution, it can be assumed that the contribution of $\mathrm{SO}_{2}$ deposition to the sea surface was very small.

Fig. 6 shows the variation in $N_{\mathrm{a}}$ and $\mathrm{CN}$ concentration within the SML with $\sigma$ plotted as variability bars. Both $N_{\mathrm{a}}$ and $\mathrm{CN}$ concentrations increase rapidly during the first $4 \mathrm{~h}$ of the Lagrangian, with $\mathrm{CN}$ values reaching $5000 \mathrm{~cm}^{-3}$ and $N_{\mathrm{a}}$ reaching $1500 \mathrm{~cm}^{-3}$. These increases coincide with the increase in $N_{\mathrm{d}}$, cloud thickness and cloud top $r_{\mathrm{e}}$ shown in Figs. 1, 3. This implies that the increase 


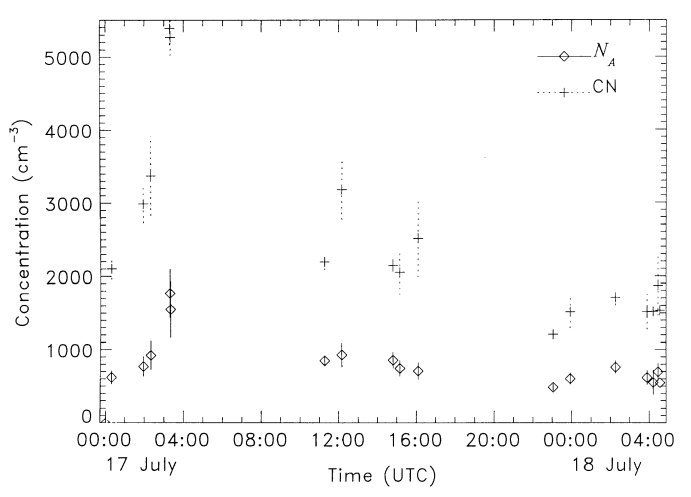

Fig. 6. Time series of the variation in accumulation mode aerosol particle concentration $\left(N_{\mathrm{a}}\right.$; diamonds with solid vertical lines showing \pm 1 standard deviation) and condensation nuclei $(\mathrm{CN})$ concentration (crosses with dotted vertical lines showing \pm 1 standard deviation) within the surface-mixed layer during the Lagrangian between 17-18 July 1997. The data are from both boxes and profiles.

in $N_{\mathrm{d}}$ was due to an increase of fresh CCN (a subset of $N_{\mathrm{a}}$ ) into the MBL. The increase in $r_{\mathrm{e}}$ was caused by the increase in cloud thickness; this exemplifies that the cloud microphysics is much more sensitive to changes in cloud depth than to changes in $N_{\mathrm{d}}$.

There was a large reduction in both $\mathrm{CN}$ and $N_{\mathrm{a}}$ between 4 and $11 \mathrm{~h}$ into the experiment which anti-correlates with the increased depth of the boundary layer shown in Fig. 1, thereby inferring dilution is a probable cause of this reduction. Dry deposition of aerosol particles is only likely to account for $5-10 \%$ at most per day. The reduction in $\mathrm{CN}$ and $N_{\mathrm{a}}$ by about $50 \%$ is not as great as the loss in $\mathrm{SO}_{2}$ within the SML over the same period (about $75 \%$ ) indicating an additional loss mechanism for the $\mathrm{SO}_{2}$ such as cloud processing or reaction with sea-salt particles.

Over the $\sim 18 \mathrm{~h}$ between the start of A559 and the end of the experiment $\mathrm{CN}$ and $N_{\mathrm{a}}$ reduced at average rates of 59 and $44 \%$ day $^{-1}$, i.e., much greater than the loss rate due to drizzle washout during A558. This trend is the inverse of the gradual increase in $N_{\mathrm{d}}$, which shows that MBL dynamics (i.e., the increase in vertical wind speed and hence peak supersaturation at cloud base) probably played an important role in determining the number of droplets activated.

Concentrations of $\mathrm{CN}$ and $N_{\mathrm{a}}$ from profile data through the Lagrangian are shown in Fig. 7. Note the annotations showing the presence of cloud showing the effects of droplet shattering on the aerosol measurements. The pollution layer at the start of the Lagrangian starts at the surface and rises to over $1500 \mathrm{~m}$ based on concentrations of $\mathrm{CN}$. There seems to be no capping inversion to the pollution, although the pollution sits in a relatively moist layer during A558. Fig. 8 shows carbon monoxide and ozone mixing ratios for the same profiles in Fig. 7. The residual continental boundary layer can also be discerned by the relatively high mixing ratios of $\mathrm{CO}$ (and $\mathrm{O}_{3}$ ) in profile $\mathrm{P} 2$ of $\mathrm{A} 558$ between $550 \mathrm{~m}$ and $2000 \mathrm{~m}$ in height. $\mathrm{CO}$ is a reasonable tracer for continental air because of its photochemical lifetime of about 1 month in the summer (Parish et al., 1993). Elevated mixing ratios of $\mathrm{O}_{3}$ and (in particular) $\mathrm{CO}$ are correlated with layers of $\mathrm{CN}$ in other profiles such as P4 in A558, P2 in A559, and P1 in A560.

The EPL during the first profile in flight A558 sits just above the cloud top (i.e., this is not an artefact of cloud droplet shattering). The relative humidity within the EPL was $95.0 \pm 1.3 \%$ and so was likely to contain deliquesced aerosol. Concentrations of $\mathrm{CN}$ during a box pattern reached $13000 \mathrm{~cm}^{-3}$ while highly correlated $N_{\mathrm{a}}$ reached over $2000 \mathrm{~cm}^{-3}$ at times. CO mixing ratios were also highest within this EPL at about $110 \mathrm{ppb}$. The EPL was present above the stratocumulus until the end of A558 (i.e., after $4 \mathrm{~h}$ of the experiment) when it was entrained into the cloud and MBL as the inversion started to rise in height. This explains the rise in aerosol loadings in the MBL mentioned above and hence explains the modification of the cloud microphysics due to an increase in available CCN.

$\mathrm{CO}$ mixing ratios remain fairly constant throughout the Lagrangian in the MBL at 95-100 ppb, which is generally low for continental airmasses. Values were not diluted as the MBL grew in the manner that the aerosol did. This was probably due to entrainment acting to top-up the MBL from the FT, where values in the FT were higher than the MBL at the start of the period.

$\mathrm{O}_{3}$ measurements made upon RV Vodyanitskiy at the start of the experiment showed average concentrations of $33.6 \pm 0.6 \mathrm{ppbv}$, which compare very favourably with the SML measurements of the $\mathrm{C}-130$ in Fig. 8. MBL mixing ratios of $\mathrm{O}_{3}$ 

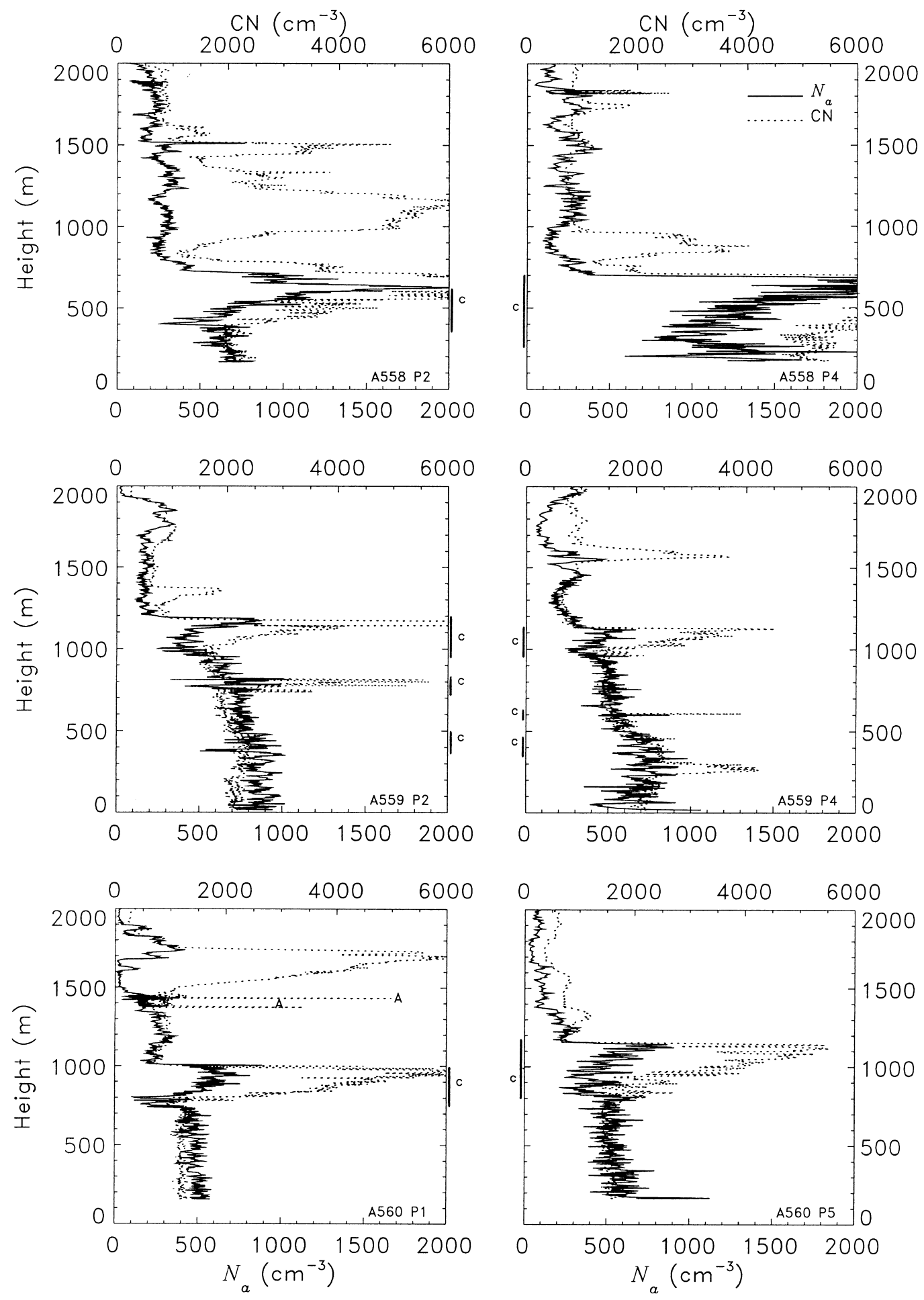
increased from $\sim 35 \mathrm{ppbv}$ in A558 to $45-50 \mathrm{ppbv}$ in A560. The $\mathrm{O}_{3}$ budget can be accounted for by simple mixing with the lower FT where values were $\sim 60 \mathrm{ppb}$.

There were a number of observations in the FT where there was an increase in $\mathrm{CN}$ but no associated increase in $N_{\mathrm{a}}$, i.e., an increase in concentration of particles less than $0.1 \mu \mathrm{m}$ in diameter. This occurs, for example, in profile P4 during A558 at $900 \mathrm{~m}$ altitude where there is also a slight anticorrelation with $N_{\mathrm{a}}$. Although very speculative, these higher loadings of $\mathrm{CN}$ may be the result of recently nucleated particles. Generally, FT concentrations of $\mathrm{CN}, N_{\mathrm{a}}$ and $\mathrm{SO}_{2}$ were lower than the MBL during A559 and A560 and so entrainment would tend to dilute the MBL.

\subsection{Hydrated aerosol spectra}

Fig. 9 shows a series of 4 aerosol size spectra between particle sizes of $0.1-0.5 \mu \mathrm{m}$ below the stratocumulus at different times within the first $3.5 \mathrm{~h}$ of the experiment, together with a spectrum from above the cloud within the EPL. Variability bars of $\pm \sigma$ for the 0325 UTC spectrum have been plotted in order to illustrate the significance of the changes. The concentration of particles is higher in the EPL relative to the MBL, with these particles lying at sizes smaller than $0.3 \mu \mathrm{m}$ and the accumulation mode lying below $0.1 \mu \mathrm{m}$. The SML spectra show an increase in the small particles with time and the shape approaches that of the EPL. In the MBL at 0015 UTC the accumulation mode lies at $0.2 \mu \mathrm{m}$, while at 0320 UTC the mode lies at a size smaller than $0.1 \mu \mathrm{m}$; this implies a transition from previously cloud-processed aerosol to aerosol previously un-processed by clouds. These spectra suggest that entrainment of the EPL into the MBL through cloud top significantly affected the aerosol spectrum in the MBL and thereby the CCN characteristics based on the modification of the stratocumulus. They also imply that entrainment of the EPL occurred on a faster time scale than the rate of processing of the entrained aerosol by the cloud.

Fig. 10 illustrates the evolution of the aerosol size distribution within the SML between particles sizes of $0.1-0.5 \mu \mathrm{m}$ throughout the Lagrangian. 5 spectra (each averaged over $\sim 30 \mathrm{~min}$ ) have been selected, one from A558, two from A559, and two from A560. Variability bars of $\pm \sigma$ in each size bin have been plotted in Fig. 10 for the 0000 UTC spectrum in A560. The figure shows development of a bimodal spectrum between A558 and the start of A559. Such spectral shapes are consistent with previous observations of the effects of cloud processing of aerosol and the observation of the large reduction in $\mathrm{SO}_{2}$. The low values of $\mathrm{H}_{2} \mathrm{O}_{2}$ during P4 of A558 (Fig. 4) between 100-500 m altitude probably reflects a sink by reacting as an oxidant during the conversion of dissolved $\mathrm{SO}_{2}$ to sulphate within cloud water. The reaction of the other main oxidant, $\mathrm{O}_{3}$, is very $\mathrm{pH}$-dependant and becomes very inefficient below around $\mathrm{pH} 4.5$. For this reason $\mathrm{H}_{2} \mathrm{O}_{2}$ is probably the main oxidant in clouds (Jenkins et al., 1996). Values of $\mathrm{H}_{2} \mathrm{O}_{2}$ recover during A559 presumably due to a continuous source of higher concentrations in the lower FT as seen in all the profiles in Fig. 4.

The minimum between the two modes (the Hoppel dip) indicates the cut-off between $\mathrm{CCN}$ (and cloud residual particles at larger sizes) and interstitial aerosol. Turbulent fluctuations in updraught velocity and hence the maximum supersaturation at cloud base blurs any sharply defined cut-off size. Also, the gap will tend to be slowly and continually filled in by other processes growing particles into the size region of the Hoppel dip and possibly by entrainment of particles of this size from the FT.

The bimodal appearance is greater towards the start of flight A559 than $3 \mathrm{~h}$ or so later. This indicates the most significant processing of the aerosol occurred between $4-11 \mathrm{~h}$ into the experi-

Fig. 7. A series of profiles from the Lagrangian between 16-18 July 1997 showing the height variation below $2 \mathrm{~km}$ of accumulation mode aerosol particle concentration $\left(N_{\mathrm{a}}\right.$, solid line using the lower abscissa in each profile) and total condensation nuclei $(\mathrm{CN})$ concentration (dotted line using the upper abscissa in each profile). The same profiles have been used as in Fig. 4 and are again labelled in the individual plots above. The vertical lines annotated "C" indicate when the aircraft was in cloud and creating spurious effects of in-cloud droplet shattering on the measurements. The annotation " $\mathrm{A}$ " indicates when the profile was interrupted and the aircraft was performing a turn, thereby also creating spurious effects. 

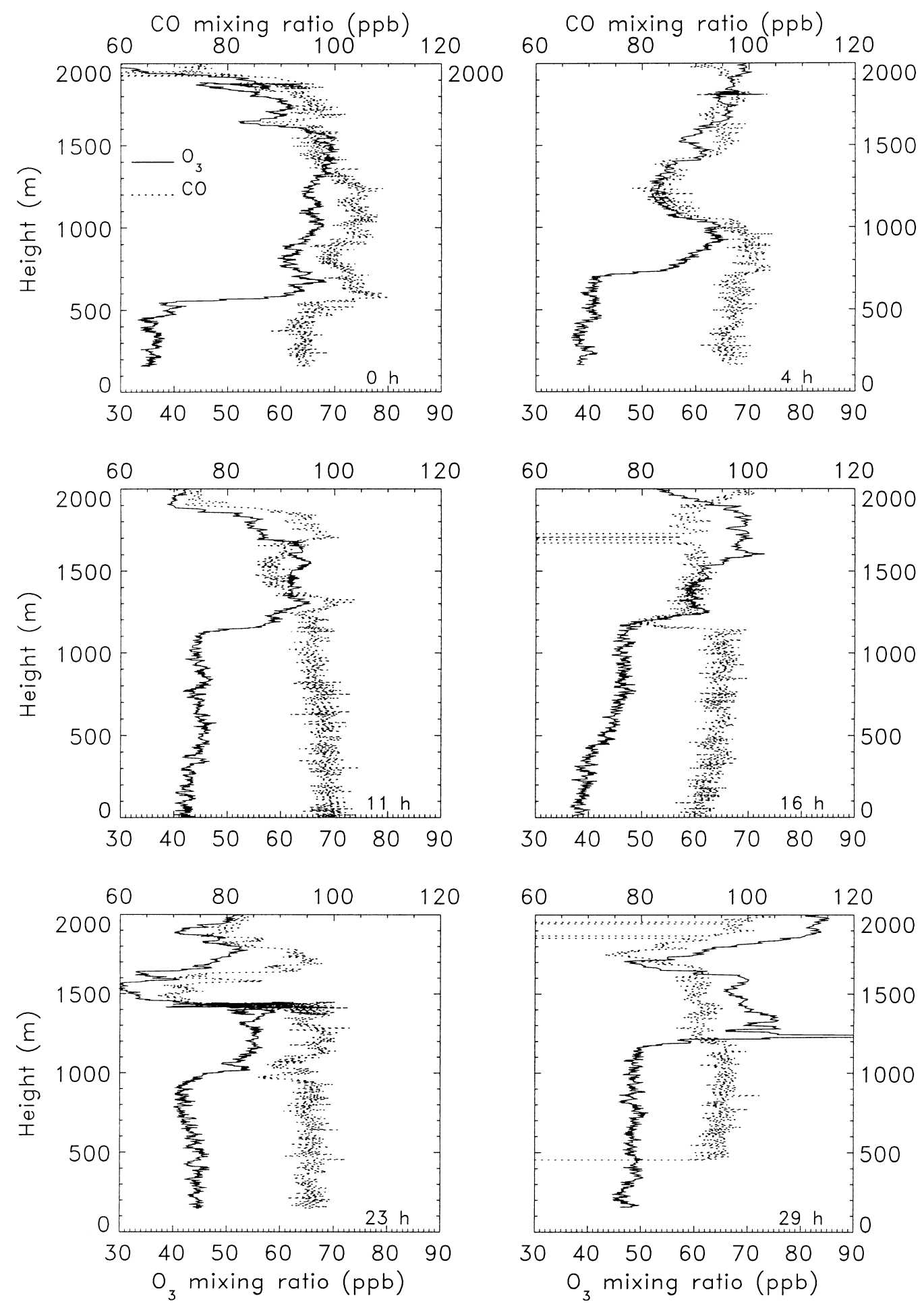


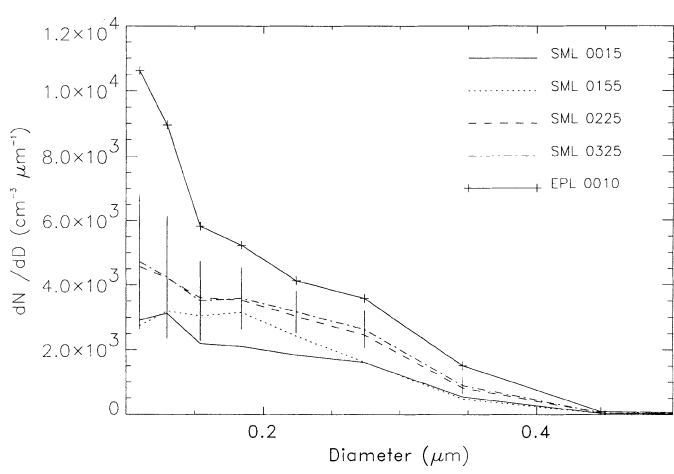

Fig. 9. Hydrated aerosol size distributions between particle sizes of 0.1 and $0.5 \mu \mathrm{m}$ in diameter at various times (in UTC) within the surface-mixed layer (SML) during the first $4 \mathrm{~h}$ of the experiment (A558 on 17 July 1997) together with one spectrum from within the elevated pollution layer (EPL) above the inversion. Variability bars of \pm 1 standard deviation have been placed on the SML spectrum at 0225 UTC. The spectra are averages through coherent layers in profiles except for the spectrum 0225 UTC within the SML which is averaged over a box pattern.

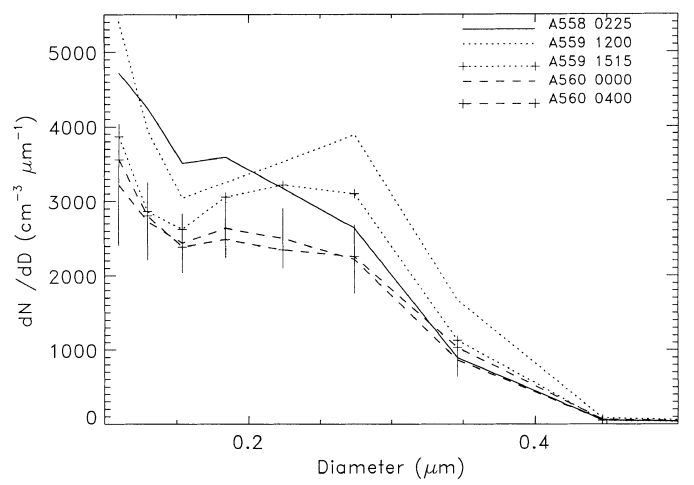

Fig. 10. Hydrated aerosol size distributions between particle sizes of 0.1 and $0.5 \mu \mathrm{m}$ in diameter within the surface-mixed layer of the Lagrangian between 16-18 July 1997. The spectra are averages over box patterns, i.e., approximately $30 \mathrm{~min}$ of sampling for each spectrum. The times in the key are UTC and are half-way through each box. Variability bars of \pm 1 standard deviation have been added to the A560 0000 UTC spectrum. ment. The Hoppel-type dip is very apparent in the two spectra from A559. Between A559 and A560, the cloud residual mode reduces in magnitude and the modal diameter decreases, although the Hoppel dip remains stationary. The spectral changes during A560 are smaller than the variability and so are not statistically significant. The reduction in concentration over the accumulation mode between A559 and A560 could intuitively be explained through dilution by entrainment of cleaner air through the inversion and/or by droplet coalescence and hence processing of the $\mathrm{CCN}$ which results in larger $\mathrm{CCN}$ but of lower number.

Within the cumulus layer of A559 (data not shown here), a similar spectral shape was observed to that in the SML (i.e., the Hoppel dip and cloud residual mode were in identical positions) but with reduced number concentrations. Additionally the concentration reduced in the accumulation mode with time within the cumulus layer. Droplet coalescence and entrainment are two processes that could explain both the reduction in time and the generally lower concentrations relative to the SML.

Spectra measured in the lower FT all show lower concentrations within the accumulation mode throughout the experiment, except for the EPL in A558. Entrainment of this EPL with its aerosol and trace gases could explain the strong processing that formed the spectra observed during A559. Subsequent to this event, entrainment of FT aerosol into the MBL cannot explain the appearance of the new mode as it would act to dilute the MBL.

\subsection{Dehydrated aerosol spectra}

Dehydrated aerosol spectra (i.e., sample heated to approximately $313 \mathrm{~K}$ ) were measured within the Aitken mode using a scanning mobility particle sizer (SMPS) and over the accumulation mode using the counter-flow virtual impactor (CVI).

Changes in the dehydrated aerosol spectra within the SML are shown in Fig. 11. The spectrum shown by the crosses is from the EPL in

Fig. 8. A series of 6 profiles, 2 from each flight of the Lagrangian between 16-18 July 1997, showing $\mathrm{O}_{3}$ mixing ratio (solid line using the lower abscissa in each profile) and CO mixing ratio (dotted line using the upper abscissa in each profile) below $2 \mathrm{~km}$ (i.e., the same profiles as used in Fig. 7). The spikes tending to small $\mathrm{CO}$ mixing ratios in A558 P2, A559 P4 and A560 P5 are not real, but caused by a routinely performed zeroing procedure.

Tellus 52B (2000), 2 


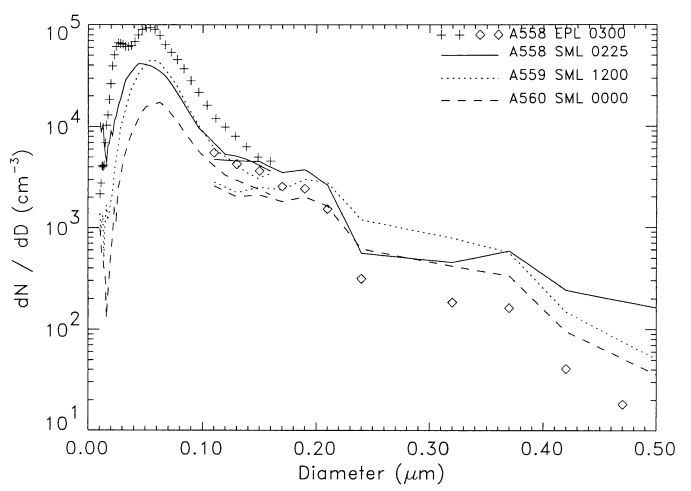

Fig. 11. Dehydrated aerosol size distributions using the SMPS and CVI PCASP covering the Aitken mode and lower end of the accumulation mode within the surfacemixed layer (SML) of A558, A559 and A560 together with a spectrum representative of the elevated pollution layer (EPL) above cloud top in A558. The spectra are averages over box patterns, i.e., approximately $30 \mathrm{~min}$ of sampling for each spectrum. The times (in UTC) given in the key are from half-way through each box.

A558 where the aerosol within the EPL is bimodal over the Aitken range with local maxima at 0.015 and $0.045 \mu \mathrm{m}$. Concentrations in the Aitken mode are much greater within the EPL than the SML (shown by the solid line) in A558. The EPL spectrum is representative of the aerosol entrained from the FT into MBL over the first $4 \mathrm{~h}$ of the experiment (Fig. 9). The accumulation mode of the EPL aerosol is present in the form of a "bulge" off the dominant Aitken mode at just under $0.2 \mu \mathrm{m}$.

The SML Aitken mode lies at $0.03 \mu \mathrm{m}$, i.e., smaller than the principal mode in the EPL. In A559 the Aitken mode has grown to $0.045 \mu \mathrm{m}$ and the number concentration has increased slightly. This shift could be due to self-coagulation of the particles and by entrainment of the aerosol within the EPL into the MBL (considering the increase in concentration).

The lower limb of the Aitken mode reduced markedly between A558 and A559 and continued to do so between A559 and A560 as well. This shows that the source of ultra-fine particles has been removed and coagulation and/or dilution is reducing their concentration. The cessation of ultra-fine particle production is consistent with the reduction of $\mathrm{SO}_{2}$ concentrations through the experiment. The Aitken mode in A560 had grown slightly to $0.05 \mu \mathrm{m}$ although the concentrations were much reduced. Dilution of the MBL aerosol with FT aerosol could explain this rapid reduction.

The total CVI PCASP particle concentration (covering the size range $0.1-10 \mu \mathrm{m}$ ) within the SML reduced gradually from $\sim 1250 \mathrm{~cm}^{-3}$ during A558 ( $\sim 2 \mathrm{~h}$ into the experiment) to $\sim 670 \mathrm{~cm}^{-3}$ during A560, i.e., nearly a halving of the concentration during a $\sim 28-h$ period which compares favourably with the MRF PCASP concentrations shown in Fig. 6. This can be seen in Fig. 11 by the reduction of the magnitude of the spectra between 0.1 and $0.2 \mu \mathrm{m}$ where most of the particles lie. This reduction could be due to dilution through entrainment of cleaner air from the FT or by cloud processing in the form of nucleation scavenging (and subsequent growth) and interstitial scavenging.

The accumulation mode generally contained higher concentrations in the SML compared to the EPL. This may be due to the effects of cloud processing. The modal variations of the SML dehydrated spectra are quite subtle compared to the hydrated aerosol, yet higher concentrations were seen during A559 between 0.20 and $0.35 \mu \mathrm{m}$. The high concentrations in A558 between 0.35 and $0.5 \mu \mathrm{m}$ were due to relatively high sea-salt loadings. This was particularly observed in the super-micron particles (data not shown here).

The dehydrated cloud residual mode was situated at smaller sizes than the equivalent hydrated mode (Fig. 10). The CVI dried the aerosol such that the effective modal diameter decreased through loss of water by $0.1 \mu \mathrm{m}$ which is more than a three-fold reduction in particle volume. This indicates that the particles in the MBL were highly deliquesced, which is very likely considering that the average relative humidity during the box patterns as used in Fig. 11 in the SML was $99.1 \pm 0.4 \%, 95.8 \pm 0.6 \%$, and $93.4 \pm 1.3 \%$ for A558, A559 and A560 respectively. These humidities are much higher than the deliquescence points of common atmospheric particulates such as sulphates (Tang and Munkelwitz, 1994).

\section{7. $\mathrm{CCN}$ evolution}

$\mathrm{CCN}$ concentrations inferred from measured $\mathrm{CCN}$ activation spectra at $0.2 \%$ supersaturation are included in Table 2. This value of $0.2 \%$ is 
thought to be a reasonable estimate of the peak supersaturations obtained in continental stratocumulus (Martin et al., 1994) and at lower supersaturations the $\mathrm{CCN}$ counter has increased errors. Table 2 shows that $\mathrm{CCN}$ concentrations were generally higher than $N_{\mathrm{d}}$, indicating that peak supersaturations were actually lower than $0.2 \%$. Concentrations were highest in the SML and cumulus layer in A559 where they were about double $N_{\mathrm{d}}$. Within the SML, concentrations were lowest in A558, with an overall increase at the end of the experiment. Concentrations were higher in the EPL than the SML in A558 which correlates with the higher aerosol concentrations found in the EPL.

\subsection{Spectra in the surface-mixed layer}

Fig. 12 shows CCN activation spectra measured in the SML through the Lagrangian at times that correspond to the aerosol spectra in Fig. 10. Each spectrum is an average over four separate samples (i.e., one sample per leg of a box), except during A559 in the 1200 UTC spectrum, which consists of one sample only. Maximum-minimum variability bars have been plotted on three of the spectra to illustrate the significance of any changes. The largest variability was observed during A559 at

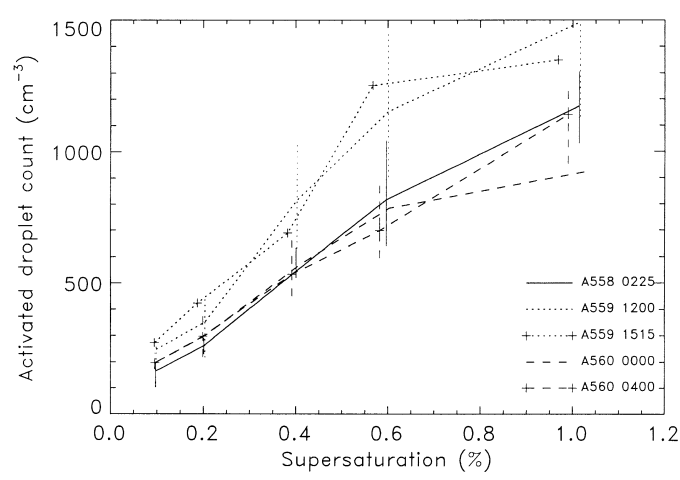

Fig. 12. Cloud condensation nuclei activation spectra measured within the surface-mixed layer through the Lagrangian of 16-18 July 1997. Each spectrum is an average of 4 samples (one per leg of a box) and the times (in UTC) given in the key are half-way through each box (except the A559 spectrum at 1515 UTC which is from one sample only). The variability bars show the maximum-minimum variation over the 4 samples during A558 at 0215 UTC (solid lines), A559 at 1200 UTC (dotted lines), and A560 at 0400 UTC (dashed lines). supersaturations above $0.3 \%$; this exemplifies the heterogeneous nature of the aerosol in the horizontal through the box pattern. The spectra in A559 show higher CCN concentrations over all supersaturations compared to the SML at the start and near the end of the period. The CCN spectra within the cumulus layer of A559 (not shown here) also had elevated concentrations but not as large as the SML. These changes coincide with the timing of the modal changes observed in the aerosol size distribution in the SML (Fig. 10) and the cumulus layer, and so cloud processing may be at least partially responsible for the changes in the CCN spectra.

At typical supersaturations experienced in stratocumulus $(0.1-0.4 \%)$, the $\mathrm{CCN}$ concentrations increased by $10-20 \%$ between the first and second flights of this Lagrangian within the SML. At supersaturations of around $0.6 \%$ (likely to be activating Aitken mode particles), there was a $50 \%$ increase in $\mathrm{CCN}$ concentration within the SML. This could be linked to the increase in the magnitude of the Aitken mode size spectrum in Fig. 11. Considering the change in the spectra over the whole period between the start of the experiment and the end, the mean $\mathrm{CCN}$ count increased at small supersaturations (less than $0.4 \%$ ), and decreased at higher supersaturations. These changes are small and the variability in the data overlaps, so the changes could be explained by heterogeneity. The high $\mathrm{CCN}$ concentrations in A559 are thought to be significant, however, because the maximum variability during A558 and A560 did not reach the mean A559 CCN curves.

\subsection{Spectra in the free troposphere}

Fig. 13 contains CCN activation spectra from above the layer of stratocumulus within the lower FT. Each spectrum is an average of four separate samples and the variability bars show the maximum-minimum values from three of these samples. All the CCN concentrations are much lower than within the MBL, except for A558 at a height of $730 \mathrm{~m}$ within the EPL where values at supersaturations $>0.1 \%$ were slightly higher than in the MBL spectra during flights A558 and A560. Therefore entrainment of CCN within the EPL can explain the increase in $N_{\mathrm{d}}$ seen at the very end of A558. The concentrations for all supersaturations were lower in the EPL of A558 than both 


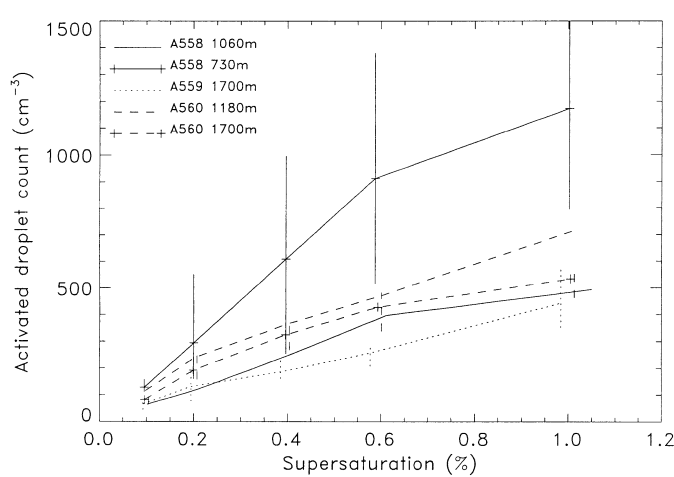

Fig. 13. Cloud condensation nuclei activation spectra measured in the lower free troposphere above the stratocumulus throughout the Lagrangian of 16-18 July 1997 , where each spectrum is an average of 4 samples (one per leg of a box). The key shows the altitude of the box patterns. The variability bars show the maximum-minimum variation over the 4 samples from A558 at $730 \mathrm{~m}$ (solid lines), A559 at $1700 \mathrm{~m}$ (dotted lines), and A560 at $1700 \mathrm{~m}$ (dashed lines).

the SML and cumulus layer spectra from A559. This latter observation indicates that processing of the aerosol modified the CCN spectrum of the entrained EPL. The variability in CCN concentrations was very large in the EPL of A558, larger than other CCN spectra in the MBL and FT over the period.

\section{Aerosol chemistry evolution}

\subsection{Fine aerosol mass}

Table 3 shows the fine soluble aerosol (i.e., $<1.4 \mu \mathrm{m}$ hydrated particle diameter) composition in the MBL and lower FT. The data are presented in molar mixing ratios (in ppt) for the principal anions and cations. Since these data are from ion chromotography analyses of filter samples, the resolution is limited to one filter (or data point) per box. Therefore, approximately $30 \mathrm{~min}$ of sampling was obtained for each set of filters which equates to be between $2.5-4.5 \mathrm{~m}^{3}$ of air. Further details on the aerosol chemistry are given by Andreae et al. (2000).

Overall, the loadings of all ions within the SML decreased over the Lagrangian, which is consistent with the overall reduction in aerosol number concentration. The mixing ratio of sulphate increased between A558 and the start of A559 both in the SML and cumulus layer, and then decreased again during A560. The mass fraction of sulphate increased from 0.68 to 0.81 over the period. The ammonium mixing ratio remained about the same in the SML (and cumulus layer) between A558 and A559 considering the overlap in the errors bars shown in Table 3, and then decreased to nearly half at the end of the experiment. Together, ammonium and sulphate account for $85-90 \%$ of the inorganic aerosol mass in the SML. Ammonium and sulphate constituted most of the aerosol mass in the EPL during A558. The ratio of ammonium to sulphate was higher in this EPL (about 2.3) compared to the SML (about 1.4), which suggests the aerosol was more acidic in the SML, i.e., a significant proportion of the aerosol was probably ammonium hydrogen sulphate compared to mostly ammonium sulphate in the EPL. This ratio remained generally below 1.5 in the SML with no obvious trend in the aerosol acidity.

The mixing ratio of nitrate in the SML doubled between A558 and A559, and then reduced markedly in A560. The mass fraction of nitrate reached a peak around $11-12 \mathrm{~h}$ into the experiment, and then decreased to low values at the end of the period. No data was available for sodium, but this can be inferred from magnesium levels assuming the calcium loadings are not too great. The mixing ratio of magnesium decreased gradually in the SML through the period, as did chloride. Although the reduction in wind speed implies a reduction in the production of sea-salt particles, the residence time of sub-micron particles is at least several days (and particles up to $1.4 \mu \mathrm{m}$ not much less than this), so there must have been a loss mechanism. The increase in sulphate through the period and nitrate during the middle of the experiment could be explained through aqueous-phase production.

\subsection{Coarse aerosol mass}

Table 4 shows the variation in large (i.e., $>1.4 \mu \mathrm{m}$ particle diameter) aerosol particle molar mixing ratios. Sodium and potassium have been added in addition to the same ions detected in Table 3. Sodium and chloride dominate the coarse aerosol mass although they decrease with time. The decrease in sodium chloride is consistent with the drop in wind speed through the period, i.e., a reduction in the source of coarse mode particles 
Table 3. Principal soluble aerosol anions and cations from the second Lagrangian for ambient aerosol particles of diameters $<1.4 \mu \mathrm{m}$ at various times since the start of the experiment

\begin{tabular}{|c|c|c|c|c|c|c|c|c|c|}
\hline Layer & $\begin{array}{l}\text { Time } \\
\text { (h) }\end{array}$ & $\begin{array}{l}\text { Height } \\
(\mathrm{m})\end{array}$ & $\begin{array}{l}\mathrm{NH}_{4}^{+} \\
(\mathrm{ppt})\end{array}$ & $\begin{array}{c}\mathrm{Mg}^{2+} \\
\text { (ppt) }\end{array}$ & $\begin{array}{l}\mathrm{Ca}^{2+} \\
(\mathrm{ppt})\end{array}$ & $\begin{array}{l}\mathrm{Cl}^{-} \\
(\mathrm{ppt})\end{array}$ & $\begin{array}{l}\mathrm{NO}_{3}^{-} \\
(\mathrm{ppt})\end{array}$ & $\begin{array}{l}\mathrm{SO}_{4}^{2-} \\
\text { (ppt) }\end{array}$ & $\mathrm{SO}_{4}^{2-}$ frac \\
\hline \multicolumn{10}{|c|}{ Flight A558 } \\
\hline LFT & 1 & 1060 & $\begin{array}{c}443 \\
{[116]}\end{array}$ & $\begin{array}{c}7 \\
{[1]}\end{array}$ & $\begin{array}{c}44 \\
{[39]}\end{array}$ & $\begin{array}{l}<40 \\
{[38]}\end{array}$ & $\begin{array}{c}81 \\
{[7]}\end{array}$ & $\begin{array}{c}191 \\
{[22]}\end{array}$ & 0.53 \\
\hline SML & 2 & 210 & $\begin{array}{c}\mathbf{2 3 6 0} \\
{[174]}\end{array}$ & $\begin{array}{c}73 \\
{[4]}\end{array}$ & $\begin{array}{c}180 \\
{[39]}\end{array}$ & $\begin{array}{c}\mathbf{2 9 4} \\
{[38]}\end{array}$ & $\begin{array}{l}156 \\
{[7]}\end{array}$ & $\begin{array}{l}\mathbf{1 6 5 2} \\
{[84]}\end{array}$ & 0.68 \\
\hline EPL & 3.2 & 730 & $\begin{array}{c}2251 \\
{[167]}\end{array}$ & $\begin{array}{l}<1 \\
{[1]}\end{array}$ & $\begin{array}{l}<50 \\
{[43]}\end{array}$ & $\begin{array}{c}48 \\
{[42]}\end{array}$ & $\begin{array}{c}31 \\
{[8]}\end{array}$ & $\begin{array}{c}992 \\
{[51]}\end{array}$ & 0.68 \\
\hline \multicolumn{10}{|c|}{ Flight A559 } \\
\hline SML & 12 & 75 & $\begin{array}{c}\mathbf{2 2 6 3} \\
{[165]}\end{array}$ & $\begin{array}{c}36 \\
{[2]}\end{array}$ & $\begin{array}{c}56 \\
{[32]}\end{array}$ & $\begin{array}{c}\mathbf{2 7 8} \\
{[32]}\end{array}$ & $\begin{array}{l}307 \\
{[6]}\end{array}$ & $\begin{array}{c}\mathbf{2 0 1 6} \\
{[102]}\end{array}$ & 0.74 \\
\hline $\mathrm{CU}$ & 12.6 & 600 & $\begin{array}{c}2459 \\
{[180]}\end{array}$ & $\begin{array}{c}30 \\
{[2]}\end{array}$ & $\begin{array}{c}88 \\
{[38]}\end{array}$ & $\begin{array}{c}53 \\
{[37]}\end{array}$ & $\begin{array}{l}324 \\
{[7]}\end{array}$ & $\begin{array}{l}1773 \\
{[90]}\end{array}$ & 0.71 \\
\hline LFT & 14.3 & 1600 & $\begin{array}{c}490 \\
{[109]}\end{array}$ & $\begin{array}{c}5 \\
{[1]}\end{array}$ & $\begin{array}{c}128 \\
{[36]}\end{array}$ & $\begin{array}{c}83 \\
{[35]}\end{array}$ & $\begin{array}{l}118 \\
{[6]}\end{array}$ & $\begin{array}{c}233 \\
{[20]}\end{array}$ & 0.48 \\
\hline SML & 15 & 75 & $\begin{array}{c}\mathbf{2 1 0 6} \\
{[153]}\end{array}$ & $\begin{array}{c}\mathbf{2 5} \\
{[2]}\end{array}$ & $\begin{array}{c}\mathbf{6 6} \\
{[26]}\end{array}$ & $\begin{array}{c}\mathbf{1 5 6} \\
{[25]}\end{array}$ & $\begin{array}{l}182 \\
{[4]}\end{array}$ & $\begin{array}{l}1522 \\
{[77]}\end{array}$ & 0.73 \\
\hline \multicolumn{10}{|c|}{ Flight A560 } \\
\hline SML & 24 & 180 & $\begin{array}{c}\mathbf{1 9 8 9} \\
{[144]}\end{array}$ & $\begin{array}{c}\mathbf{2 0} \\
{[1]}\end{array}$ & $\begin{array}{l}<\mathbf{3 0} \\
{[23]}\end{array}$ & $\begin{array}{c}\mathbf{6 5} \\
{[23]}\end{array}$ & $\begin{array}{c}31 \\
{[4]}\end{array}$ & $\begin{array}{l}\mathbf{1 2 4 9} \\
{[63]}\end{array}$ & 0.75 \\
\hline LFT & 25 & 1200 & $\begin{array}{c}770 \\
{[124]}\end{array}$ & $\begin{array}{l}<1 \\
{[1]}\end{array}$ & $\begin{array}{c}70 \\
{[41]}\end{array}$ & $\begin{array}{l}<40 \\
{[40]}\end{array}$ & $\begin{array}{l}214 \\
{[7]}\end{array}$ & $\begin{array}{c}336 \\
{[23]}\end{array}$ & 0.79 \\
\hline LFT & 26 & 1650 & $\begin{array}{c}1124 \\
{[128]}\end{array}$ & $\begin{array}{c}34 \\
{[2]}\end{array}$ & $\begin{array}{c}323 \\
{[43]}\end{array}$ & $\begin{array}{c}48 \\
{[42]}\end{array}$ & $\begin{array}{l}346 \\
{[7]}\end{array}$ & $\begin{array}{c}535 \\
{[28]}\end{array}$ & 0.47 \\
\hline LFT & 27.5 & 1650 & $\begin{array}{l}1012 \\
{[83]}\end{array}$ & $\begin{array}{c}33 \\
{[2]}\end{array}$ & $\begin{array}{c}321 \\
{[28]}\end{array}$ & $\begin{array}{l}<30 \\
{[27]}\end{array}$ & $\begin{array}{l}116 \\
{[5]}\end{array}$ & $\begin{array}{c}479 \\
{[25]}\end{array}$ & 0.53 \\
\hline SML & 28 & 180 & $\begin{array}{l}\mathbf{1 3 2 6} \\
{[97]}\end{array}$ & $\begin{array}{c}\mathbf{2 0} \\
{[1]}\end{array}$ & $\begin{array}{c}18 \\
{[22]}\end{array}$ & $\begin{array}{c}\mathbf{5 8} \\
{[21]}\end{array}$ & $\begin{array}{c}45 \\
{[4]}\end{array}$ & $\begin{array}{l}1268 \\
{[64]}\end{array}$ & 0.81 \\
\hline
\end{tabular}

The errors printed below the appropriate measurement are the greater of either (1) the analytical error of the ion chromotography measurement (4-10\%, depending on species) or (2) two times the standard deviation of blank control filters. The different layers are surface-mixed layer (SML), lower free troposphere (LFT), and cumulus (CU) layer. The final column shows the sulphate mass as a fraction of the total analysed soluble mass.

which have a shorter residence time than submicron aerosol. The brief lull in the MBL winds during A559 occurred on too small a time scale to be evident in the amount of sea-salt in the filter samples. Sulphate increases (as with the fine aerosol mass) to reach a peak in A559, although the mass fraction increases gradually through the period. Ammonium mixing ratios are very low compared to the fine aerosol particles, but values are highest in A560. Nitrate increases by an order of magnitude in the SML between A558 and A559, reaching a peak $11-12 \mathrm{~h}$ into the experiment (similar to the fine aerosol mass), then dropping off in
A560. Based on the trends of the nitrate and sulphate in the coarse mode, perhaps the same processes were acting within both the accumulation and coarse modes. The high levels of calcium in the SML and lower FT in A558 and the lower FT A560 may be attributable to a mineral aerosol source not over Europe but over North Africa.

\section{Summary}

The analysis of the Lagrangian experiment between 16-18 July 1997 within a polluted out- 
Table 4. Principal soluble aerosol anions and cations from the second Lagrangian for ambient aerosol particles of diameters $>1.4 \mu \mathrm{m}$ at various times since the start of the experiment

\begin{tabular}{|c|c|c|c|c|c|c|c|c|c|c|c|}
\hline Layer & $\begin{array}{l}\text { Time } \\
\text { (h) }\end{array}$ & $\begin{array}{l}\text { Height } \\
(\mathrm{m})\end{array}$ & $\begin{array}{l}\mathrm{Na}^{+} \\
(\mathrm{ppt})\end{array}$ & $\begin{array}{l}\mathrm{NH}_{4}^{+} \\
\text {(ppt) }\end{array}$ & $\begin{array}{c}\mathrm{K}^{+} \\
(\mathrm{ppt})\end{array}$ & $\begin{array}{l}\mathrm{Mg}^{2+} \\
(\mathrm{ppt})\end{array}$ & $\begin{array}{l}\mathrm{Ca}^{2+} \\
\text { (ppt) }\end{array}$ & $\begin{array}{l}\mathrm{Cl}^{-} \\
(\mathrm{ppt})\end{array}$ & $\begin{array}{l}\mathrm{NO}_{3}^{-} \\
(\mathrm{ppt})\end{array}$ & $\begin{array}{l}\mathrm{SO}_{4}^{2-} \\
\text { (ppt) }\end{array}$ & $\mathrm{SO}_{4}^{2-}$ frac \\
\hline \multicolumn{12}{|c|}{ Flight $\mathbf{A 5 5 8}$} \\
\hline LFT & 1 & 1060 & $\begin{array}{c}333 \\
{[109]}\end{array}$ & $\begin{array}{c}29 \\
{[35]}\end{array}$ & $\begin{array}{c}40 \\
{[37]}\end{array}$ & $\begin{array}{c}73 \\
{[8]}\end{array}$ & $\begin{array}{c}410 \\
{[21]}\end{array}$ & $\begin{array}{c}270 \\
{[32]}\end{array}$ & $\begin{array}{l}<20 \\
{[15]}\end{array}$ & $\begin{array}{c}259 \\
{[17]}\end{array}$ & 0.39 \\
\hline SML & 2 & 210 & $\begin{array}{c}1498 \\
{[110]}\end{array}$ & $\begin{array}{l}<\mathbf{4 0} \\
{[35]}\end{array}$ & $\begin{array}{l}106 \\
{[37]}\end{array}$ & $\begin{array}{c}\mathbf{2 1 6} \\
{[13]}\end{array}$ & $\begin{array}{c}353 \\
{[18]}\end{array}$ & $\begin{array}{c}991 \\
{[63]}\end{array}$ & $\begin{array}{l}<\mathbf{2 0} \\
{[16]}\end{array}$ & $\begin{array}{c}\mathbf{2 5 9} \\
{[17]}\end{array}$ & 0.21 \\
\hline EPL & 3.2 & 730 & $\begin{array}{r}<130 \\
{[122]}\end{array}$ & $\begin{array}{c}31 \\
{[39]}\end{array}$ & $\begin{array}{c}30 \\
{[41]}\end{array}$ & $\begin{array}{c}26 \\
{[9]}\end{array}$ & $\begin{array}{c}316 \\
{[16]}\end{array}$ & $\begin{array}{r}<40 \\
{[35]}\end{array}$ & $\begin{array}{c}31 \\
{[17]}\end{array}$ & $\begin{array}{c}64 \\
{[19]}\end{array}$ & 0.22 \\
\hline \multicolumn{12}{|c|}{ Flight A559 } \\
\hline SML & 12 & 75 & $\begin{array}{l}\mathbf{1 0 0 5} \\
{[10]}\end{array}$ & $\begin{array}{c}\mathbf{8} \\
{[7]}\end{array}$ & $\begin{array}{c}28 \\
{[4]}\end{array}$ & $\begin{array}{l}\mathbf{1 0 2} \\
{[6]}\end{array}$ & $\begin{array}{c}93 \\
{[10]}\end{array}$ & $\begin{array}{c}498 \\
{[32]}\end{array}$ & $\begin{array}{l}\mathbf{2 1 8} \\
{[5]}\end{array}$ & $\begin{array}{c}299 \\
{[16]}\end{array}$ & 0.32 \\
\hline $\mathrm{CU}$ & 12.6 & 600 & $\begin{array}{c}518 \\
{[12]}\end{array}$ & $\begin{array}{c}28 \\
{[9]}\end{array}$ & $\begin{array}{c}14 \\
{[5]}\end{array}$ & $\begin{array}{c}44 \\
{[7]}\end{array}$ & $\begin{array}{c}79 \\
{[12]}\end{array}$ & $\begin{array}{c}179 \\
{[14]}\end{array}$ & $\begin{array}{l}152 \\
{[3]}\end{array}$ & $\begin{array}{c}232 \\
{[13]}\end{array}$ & 0.40 \\
\hline LFT & 14.3 & 1600 & $\begin{array}{c}59 \\
{[12]}\end{array}$ & $\begin{array}{l}<10 \\
{[8]}\end{array}$ & $\begin{array}{c}30 \\
{[5]}\end{array}$ & $\begin{array}{l}<10 \\
{[7]}\end{array}$ & $\begin{array}{c}178 \\
{[12]}\end{array}$ & $\begin{array}{c}23 \\
{[13]}\end{array}$ & $\begin{array}{c}69 \\
{[2]}\end{array}$ & $\begin{array}{c}29 \\
{[2]}\end{array}$ & 0.16 \\
\hline SML & 15 & 75 & $\begin{array}{c}1102 \\
{[8]}\end{array}$ & $\begin{array}{l}<10 \\
{[6]}\end{array}$ & $\begin{array}{c}28 \\
{[3]}\end{array}$ & $\begin{array}{l}114 \\
{[7]}\end{array}$ & $\begin{array}{c}\mathbf{5 6} \\
{[8]}\end{array}$ & $\begin{array}{c}\mathbf{6 6 0} \\
{[42]}\end{array}$ & $\begin{array}{l}189 \\
{[4]}\end{array}$ & $\begin{array}{c}\mathbf{2 7 4} \\
{[14]}\end{array}$ & 0.28 \\
\hline \multicolumn{12}{|c|}{ Flight A560 } \\
\hline SML & 24 & 180 & $\begin{array}{l}672 \\
{[7]}\end{array}$ & $\begin{array}{c}\mathbf{6 6} \\
{[5]}\end{array}$ & $\begin{array}{c}11 \\
{[3]}\end{array}$ & $\begin{array}{c}\mathbf{7 5} \\
{[5]}\end{array}$ & $\begin{array}{l}131 \\
{[7]}\end{array}$ & $\begin{array}{c}\mathbf{3 3 3} \\
{[22]}\end{array}$ & $\begin{array}{l}130 \\
{[3]}\end{array}$ & $\begin{array}{c}\mathbf{2 2 9} \\
{[12]}\end{array}$ & 0.33 \\
\hline LFT & 25 & 1200 & $\begin{array}{c}58 \\
{[13]}\end{array}$ & $\begin{array}{l}<10 \\
{[9]}\end{array}$ & $\begin{array}{c}4 \\
{[6]}\end{array}$ & $\begin{array}{c}10 \\
{[8]}\end{array}$ & $\begin{array}{c}208 \\
{[13]}\end{array}$ & $\begin{array}{l}<15 \\
{[15]}\end{array}$ & $\begin{array}{c}62 \\
{[2]}\end{array}$ & $\begin{array}{c}34 \\
{[3]}\end{array}$ & 0.18 \\
\hline LFT & 26 & 1650 & $\begin{array}{c}39 \\
{[14]}\end{array}$ & $\begin{array}{l}<10 \\
{[10]}\end{array}$ & $\begin{array}{c}7 \\
{[6]}\end{array}$ & $\begin{array}{c}33 \\
{[8]}\end{array}$ & $\begin{array}{c}454 \\
{[23]}\end{array}$ & $\begin{array}{c}80 \\
{[16]}\end{array}$ & $\begin{array}{c}99 \\
{[2]}\end{array}$ & $\begin{array}{l}126 \\
{[7]}\end{array}$ & 0.29 \\
\hline LFT & 27.5 & 1650 & $\begin{array}{c}67 \\
{[9]}\end{array}$ & $\begin{array}{l}<10 \\
{[6]}\end{array}$ & $\begin{array}{c}24 \\
{[4]}\end{array}$ & $\begin{array}{c}44 \\
{[5]}\end{array}$ & $\begin{array}{c}526 \\
{[27]}\end{array}$ & $\begin{array}{c}21 \\
{[10]}\end{array}$ & $\begin{array}{c}2 \\
{[1]}\end{array}$ & $\begin{array}{c}79 \\
{[5]}\end{array}$ & 0.23 \\
\hline SML & 28 & 180 & $\begin{array}{l}762 \\
{[7]}\end{array}$ & $\begin{array}{c}\mathbf{6 3} \\
{[5]}\end{array}$ & $\begin{array}{c}31 \\
{[3]}\end{array}$ & $\begin{array}{c}\mathbf{8 5} \\
{[5]}\end{array}$ & $\begin{array}{l}114 \\
{[7]}\end{array}$ & $\begin{array}{c}371 \\
{[24]}\end{array}$ & [3] & $\begin{array}{c}\mathbf{2 6 5} \\
{[14]}\end{array}$ & 0.34 \\
\hline
\end{tabular}

The errors printed below the appropriate measurement are the greater of either (1) the analytical error of the ion chromotography measurement (4-10\%, depending on species) or (2) two times the standard deviation of blank control filters. The different layers are surface-mixed layer (SML), lower free troposphere (LFT), and cumulus (CU) layer. The final column shows the sulphate mass as a fraction of the total analysed soluble mass.

break from the European continent over the North Atlantic has paid particular attention to the evolution of the aerosol particles, in particular looking for evidence of (1) the interaction of aerosols and cloud because there was full stratocumulus cover at all times, and (2) dynamical effects such as entrainment through the subsidence inversion. These processes have been emphasised as potentially important in previous literature.

Interpreting the aerosol evolution has not been easy due to many complicating factors that include changes in the MBL thermodynamic structure, MBL depth, surface fluxes, and entrainment of both clean and polluted aerosol through the inversion. It is the purpose of this section to summarise the salient observations of changes in the MBL, cloud physics and aerosol physics and suggest possible processes responsible for these.

Decoupling of the MBL commenced $4 \mathrm{~h}$ into the period and may have been due to evaporative cooling of drizzle drops. The subsequent decoupling in A559 was seemingly not solely caused by a diurnal effect based on the observation of cumulus overnight in A560 and so was probably due to an increasing SST, although a diurnal variation was still present (e.g., in cloud thickness). 
This was likened to the "warming-deepening" effect over warmer waters as described by Bretherton and Wyant (1997), yet the gradient in the SST in this experiment was comparatively small. A reduction in the subsidence rate in the FT may have assisted the growth of the MBL and hence decoupling of the MBL.

The gradual increase in $N_{\mathrm{d}}$ through the last $18 \mathrm{~h}$ of the experiment (at a rate of $59 \%$ day $^{-1}$ ), as $N_{\mathrm{a}}$ and $\mathrm{CN}$ concentrations concurrently decreased (at rates of $44 \%$ day $^{-1}$ and $59 \%$ day $^{-1}$ respectively), reflects the observed increase in vertical velocity increasing the peak supersaturation at cloud base. There is also the possibility that processing of the aerosol particles by the cumulus (perhaps as small as Aitken mode particles) and stratocumulus created highly soluble accumulation mode particles that acted as very efficient $\mathrm{CCN}$, and so in turn changed the cloud microphysics.

The change in the aerosol size distribution (especially at the start of A559 after $11 \mathrm{~h}$ ) suggests the processing of the spectrum into a cloud residual mode and interstitial mode separated by the Hoppel dip. The CCN activation spectra also showed a large change (across the supersaturation range $0.1-1 \%$ ) within the SML during the middle of the Lagrangian which is consistent with the largest changes seen in the aerosol spectra. The increase in sulphate fraction of the fine aerosol and the decrease in $\mathrm{SO}_{2}$ (together with low $\mathrm{H}_{2} \mathrm{O}_{2}$ values within cloud $4 \mathrm{~h}$ into the period) are also consistent with the aqueous-phase oxidation of dissolved $\mathrm{SO}_{2}$ to produce sulphate within cloud droplets. Dore et al. (2000) carry out process modelling involving sulphur and nitrogen species initialised using observations from the second Lagrangian and show that the aerosol modal development can at least be partially explained through aqueous-phase reactions.

Aerosol within the MBL at the start of the experiment had likely experienced cloud cycles in its previous history. The polluted layers above the cloud (within the residual continental boundary layer) are less likely to have encountered with cloud. The distinct aerosol and CCN spectra at the start of A559 (after $\sim 11 \mathrm{~h}$ ) perhaps suggest that aerosol within the EPL entrained into the MBL was processed by the stratocumulus (and cumulus), such that the more pronounced spectra in the SML of A559 relative to the cumulus layer probably shows the result of processing of the
EPL some hours previously during the time between A558 and A559. The cumulus layer would have been more prone to dilution through entrainment.

The relatively high mass of nitrate during the middle of the Lagrangian could also be explained by aqueous-phase (or photochemical) production of, say, $\mathrm{HNO}_{3}$. There were no observations of high levels of nitrate above the inversion to suggest entrainment of aerosol was the cause, although entrainment of precursor gases (such as $\mathrm{NO}_{x}$ which was not measured) may have occurred.

Droplet coalescence is also a process that may have reduced the concentration of CCN. Further modelling work needs to be carried out to include the effects of cloud droplet coalescence on the residual aerosol size spectrum. The large drizzle modes during A558 and A560 suggests that coalescence could have re-distributed aerosol mass along the aerosol size distribution as well as vertically within the MBL by falling and evaporating precipitation drops. For example, the difference in aerosol characteristics between the SML and cumulus layer during A559 may be partially due to re-distribution of aerosol particles by drizzle drops falling from the cumulus layer into the SML. Loss of aerosol mass through wet deposition was a very slow process even where the stratocumulus was thickest and lowest. This suggests that wet deposition within the polluted sub-tropical stratocumulus-topped MBL of the North Atlantic region is not an important process. Further analysis of the ACE-2 data needs to be carried out in clean maritime conditions to see if wet deposition is significant in such conditions.

The entrainment of the EPL 3-4 h into the period introduced Aitken and accumulation mode aerosol into the MBL, perturbing the cloud microphysics by greatly increasing $N_{\mathrm{d}}$. Because the cloud layer concurrently thickened, the increase in $N_{\mathrm{d}}$ was not realised by a decrease in cloud top $r_{\mathrm{e}}$ (as would be expected based on the Twomey effect) but an increase. This exemplifies the importance of the cloud thickness over $N_{\mathrm{d}}$ for determining $\tau$ of the cloud. This can also be seen by referring to the equation for $\tau$ for an adiabatic cloud of geometrical depth $h$ (e.g., Brenguier et al., 1999):

$\tau=\left(\frac{243 \pi}{250}\right)^{1 / 3}\left(\frac{k N_{\mathrm{d}}}{\rho_{\mathrm{w}}^{2}}\right)^{1 / 3} \Gamma_{l}^{2 / 3} \mathrm{~h}^{5 / 3}$, 
where $\rho_{\mathrm{w}}$ is the density of liquid water and $\Gamma_{l}$ is the adiabatic rate of increase of $q_{\mathrm{L}}$ with height (a function of temperature and pressure). This equation shows the relative important of $h$ (raised to the power $\frac{5}{3}$ ) over $N_{\mathrm{d}}$ (raised to the power $\frac{1}{3}$ ) in determining the optical properties of a cloud layer.

After the entrainment of the EPL during the first few hours of the experiment, entrainment introduced air of relatively low aerosol particle concentration and so diluted the MBL. This could explain the large reduction in $\mathrm{CN}, N_{\mathrm{a}}$ and $N_{\mathrm{d}}$ between the end of A558 and the start of A559 by using simple dilution factor calculations.

Sea-salt particles were most significant during the first $3-4 \mathrm{~h}$ where winds speeds were highest $\left(10-12 \mathrm{~m} \mathrm{~s}^{-1}\right)$. The chemical analyses from filters shows that sea-salt was most evident during this early period. The wind speed was greater than $8 \mathrm{~m} \mathrm{~s}^{-1}$ through most of the period and so whitecapping would have been present apart from a few hours during A559; sea-salt was probably significant in both mass and surface area terms throughout, but not in number terms (Hoell et al., 2000). Large sea-salt particles may have scavenged Aitken mode aerosol particles due to there large surface area and may be partially responsible for the observed drop in $\mathrm{CN}$ concentration.

Hoell et al. (2000) carried out an initial time scale analysis on the processes likely to be affecting the aerosol during this Lagrangian. They state that mixing of FT air into the MBL can explain the broad features of the changes in the aerosol properties, although aqueous-phase processes in clouds cannot be ruled out due to the very fast time scales over which it operates. Additionally, they show that scavenging of interstitial aerosol by cloud droplets and self-coagulation of Aitken mode particles probably contributed to some of the aerosol losses over the 29-h period, considering for example that, on average, an aerosol particle would have spent a total of about $6 \mathrm{~h}$ within cloud.

A number of processes may together provide non-linear feedback that cannot be realised by analysing individual rates of particle growth. Therefore detailed process modelling now needs to be carried out using the aircraft observations presented here in order to determine the principal processes (i.e., aerosol, cloud, dynamic, thermodynamic on all scales from micro-physical to synoptic-scale) that were responsible for modifying the aerosol and cloud microphysics, as well as the structure of the MBL. Such changes may have an impact on the direct and indirect aerosol radiative forcing within the sub-tropical region of the North Atlantic. Only once this process modelling is complete can aerosol parametrisations be developed to simulate aerosol evolution in AGCMs.

\section{Hypotheses}

To conclude this paper, hypotheses have been devised based on the observations gathered during the second Lagrangian of ACE-2, together with the work of Hoell et al. (2000), Dore et al. (2000), and Andreae et al. (2000). These hypotheses should be either substantiated or refuted by process modellers.

- Washout of aerosol in continental airmasses by drizzle processes over the sub-tropical North Atlantic is negligible; therefore cloud lifetime is increased and hence the second indirect radiative effect plays a significant role.

- Entrainment of clean FT air is the principal diluting process within the cloud-capped MBL.

- Decoupling of the sub-tropical cloud-capped MBL occurs through the "warmingdeepening" process.

- Modification of the CCN spectrum occurs through cloud processing; this, together with changes in the dynamics of the MBL, affect the cloud physics and hence the first indirect radiative effect of the aerosol.

- Conversion of dissolved $\mathrm{SO}_{2}$ to sulphate within cloud droplets rapidly depletes gaseous $\mathrm{SO}_{2}$ and grows aerosol particles into the efficient light-scattering region which modifies the direct forcing of aerosol.

\section{Acknowledgements}

This research is a contribution to the International Global Atmospheric Chemistry (IGAC) Core Project of the International Geosphere-Biosphere Programme (IGBP) and is part of the IGAC Aerosol Characterization Experiments (ACE). It has been supported by the European Union under contract ENV4-CT950032, the UK Department of the Environment, Transport and the Regions, the UK National Environment Research Council, the German Max 
Planck Society, and other national agencies in Sweden, USA, and Canada. Thanks go to Hannah Richer for useful discussions and to the C-130 aircrew of the Royal Air Force for their everprofessional service during the ACE-2 campaign in Tenerife.

\section{REFERENCES}

Albrecht, B. A. 1989. Aerosols, cloud microphysics, and fractional cloudiness. Science 245, 1227-1230.

Andreae, M. O., Berresheim, H., Andreae, T. W., Kritz, M. A., Bares, T. S. and Merrill, J. T. 1988. Vertical distribution of dimethylsulfide, sulfur dioxide, aerosol ions, and radon over the northeast pacific ocean J. Atmos. Chem. 6, 149-173.

Andreae, M. O., Elbert, W., Gabriel, R., Johnson, D. W., Osborne, S. R. and Wood, R. 2000. Soluble ion chemistry of the atmospheric aerosol and $\mathrm{SO}_{2}$ concentrations over the eastern north Atlantic during ACE-2. Tellus $\mathbf{B}$, in press.

Bower, K. N. and Choularton, T. W. 1993. Cloud processing of the cloud condensation nucleus spectrum and its climatological consequences. Quart. J. Roy. Meteorol. Soc. 119, 655-679.

Brenguier, J.-L., Pawlowska, H., Schüller, L., Preusker, R., Fischer, J. and Fouquart, Y. 1999. Radiative properties of boundary layer clouds: droplet effective radius versus droplet concentration. J. Atmos. Sci., in press.

Brenguier, J.-L., Fouquart, Y., Johnson, D. W., Parol, F., Pawlowska, H., Schüller, L., Schröder, F. and Snider, J. 2000. An overview of the ACE-2 CLOUDYCOLUMN closure experiment. Tellus 52B, 815-827.

Bretherton, C. S. and Wyant, M. C. 1997. Moisture transport, lower tropospheric stability and decoupling of cloud-topped boundary layers. J. Atmos. Sci. 54, 148-167.

Brown, P. R. A. 1993. Measurements of the ice water content in cirrus using an evaporative technique. J. Atmos. Oceanic Technol. 10, 579-590.

Clarke, A. D., Varner, J. L., Eisele, F., Maudlin, R. L., Tanner, D. and Litchy, M. 1998. Particle production in the remote marine atmosphere: Cloud outflow and subsidence during ACE-1. J. Geophys. Res. 103 (D13), $16,397-16,409$

Clegg, N. A. and Toumi, R. 1997. Sensitivity of sulphur dioxide oxidation in sea salt to nitric acid and ammonia gas phase concentrations. J. Geophys. Res. 102 (D19), 23,241-23,249.

Dore, A. J., Johnson, D. W., Choularton, T. W., Osborne, S. R. and Andreae, M. O. 2000. Evolution of boundary layer aerosol particles due to in-cloud chemical reactions during the second Lagrangian experiment of ACE-2. Tellus 52B, 452-463.

Feingold, G., Kreidenweiss, S. M., Stevens, B. and Cotton, W. R. 1996. Numerical simulations of stratocumulus processing of cloud condensation nuclei through collision-coalescence. J. Geophys. Res. 101 (D16), 21,391-21,402.
Hansen, J. E. 1971. Multiple scattering of polarized light in planetary atmospheres. Part II: sunlight reflected by terrestrial water clouds. J. Atmos. Sci. 28, 1400-1426.

Hoell, C., O'Dowd, C., Osborne, S. R. and Johnson, D. W. 2000. Timescale analysis of marine boundary layer aerosol evolution: Lagrangian case studies under clean and polluted cloudy conditions. Tellus 52B, 423-438.

Hoppel, W. A., Frick, G. M. and Larson, R. E. 1986. Effect of non-precipitating clouds on the aerosol size distribution in the marine boundary layer. Geophys. Res. Lett. 13, 125-128.

Hoppel, W. A., Frick, G. M., Fitzgerald, J. M. and Larson, R. E. 1994. Marine boundary layer measurements of new particle formation and the effects nonprecipitating clouds have on aerosol size distribution J. Geophys. Res. 99 (D7), 14,443-14,459.

IPCC 1995. Climate Change 1995: The science of climate change. Contribution of WG1 to the 2nd Assessment Report of the Intergovernmental Panel on Climate Change. Cambridge Univeristy Press. ISBN 0-521-56436-0.

Jenkin, M. E., Clement, C. F. and Ford, I. J. 1996. Gasto-particle conversion pathways. AEA Technology, First Annual Report on contract Met2a/1053/ Project 2.

Johnson, R., Businger, S. and Baerman, A. 2000. Lagrangian air mass tracking with smart balloons during ACE-2. Tellus 52B, 321-334.

Johnson, D. W., Osborne, S. R., Wood, R., Suhre, K., Andreae, M. O., Johnson, R., Businger, S., Quinn, P. K., Bates, T., Durkee, P., Jonson, H., Russell, L. M., Noone, K., Glantz, P., Bandy, B., O’Dowd, C., Rapsomanikis, S., and Rudolph, J. 2000a. An overview of the Lagrangian experiments undertaken during the North Atlantic regional Aerosol Characterisation Experiment (ACE-2). Tellus 52B, 290-320.

Johnson, D. W., Osborne, S. R., Wood, R., Suhre, K., Quinn, P. K., Bates, T. S., Andreae, M. O., Noone, K., Glantz, P., Bandy, B., Rudolph, J. and O'Dowd, C. 2000b. Observations of the evolution of the aerosol, cloud, and boundary layer characteristics during the first ACE-2 Lagrangian experiment. Tellus 52B, 348-374.

Kerminen, V. and Wexler, A. S. 1995. Growth laws for atmospheric aerosol particles: an examination of the bimodality of the accumulation mode. Atmos. Environ. 29, 3263-3275.

Martin, G. M., Johnson, D. W. and Spice, A. 1994. The measurement and parameterization of effective radius 
of droplets in warm stratocumulus clouds. J. Atmos. Sci. 51, 1823-1842.

Nicholls, S. 1984. The dynamics of stratocumulus: aircraft observations and comparisons with a mixed layer model. Quart. J. Roy. Meteorol. Soc. 110, 783-820.

Parish, D. D., Holloway, J. S., Trainer, M., Murphy, P. C., Forbes, G. L. and Fehsenfeld, F. C. 1993. Export of North American pollution to the North Atlantic Ocean. Science 259, 1436-1439.

Raes, F. 1995. Entrainment of free tropospheric aerosols as a regulating mechanism for cloud condensation nuclei in the remote marine boundary layer. J. Geophys. Res. 100 (D2), 2893-2903.

Rogers, D. P., Johnson, D. W. and Friehe, C. A. 1995. The stable internal boundary layer over a coastal sea (I). Airborne measurements of the mean and turbulence structure. J. Atmos. Sci. 52, 667-683.

Rotstyan, L. 1999. Indirect forcing by anthropogenic aerosols: A global climate model calculation of the effective-radius and cloud-lifetime effects. J. Geophy. Res. 104 (D8), 9369-9380.

Saxena, V. K. and Kassner, J. R. 1970. Thermal-diffusion chambers as cloud-nuclei counters. Proc. Symp. Precipitation scavenging (Richland, Washington, Pacific Northwest Laboratory and US Atomic Energy Commission), 217-238.

Sollazzo, M. J., Russell, L. M., Wood, R., Osborne, S. R.,
Percival, D. and Johnson, D. W. 2000. Entrainment rates during ACE-2 Lagrangian experiments calculated from aircraft measurements. Tellus 52B, 335-347. Tang, I. N. and Munkelwitz, H. R. 1994. Aerosol phase transformation and growth in the atmosphere. J. Appl. Meteorol. 33, 791-796.

Twomey, S. 1977. The influence of pollution on the shortwave albedo of clouds. J. Atmos. Sci. 34, 1149-1152.

Van Dingenen, R., Raes, F., Putaud, J.-P., Virkkula, A. and Mangoni, M. 1999. Processes determining the relationship between aerosol number and non-sea-salt sulfate mass concentrations in the clean and perturbed marine boundary layer. J. Geophys. Res. 104 (D7), 8027-8038.

Verver, G., Raes, F., Vogelezang, D. and Johnson, D. W. 2000. The second Aerosol Characterization Experiment (ACE-2): meteorological and chemical context. Tellus 52B, 126-140.

Wood, R., Johnson, D. W., Osborne, S. R., Andreae, M. O., Bandy, B., Bates, T. S., O’Dowd, C., Glantz, P., Noone, K., Quinn, P. K., Rudolph, J. and Suhre, K. 2000. Boundary layer and aerosol evolution during the third Lagrangian experiment of ACE-2. Tellus 52B, 401-422.

Yuen, P., Hegg, D. A. and Larson, T. V. 1994. The effects of in-cloud sulfate production on light-scattering properties of continental aerosol. J. Appl. Meteorol. 33, 848-854. 